\title{
Automated Mapping of Mineral Groups and Green Vegetation from Landsat Thematic Mapper Imagery with an Example from the San Juan Mountains, Colorado
}

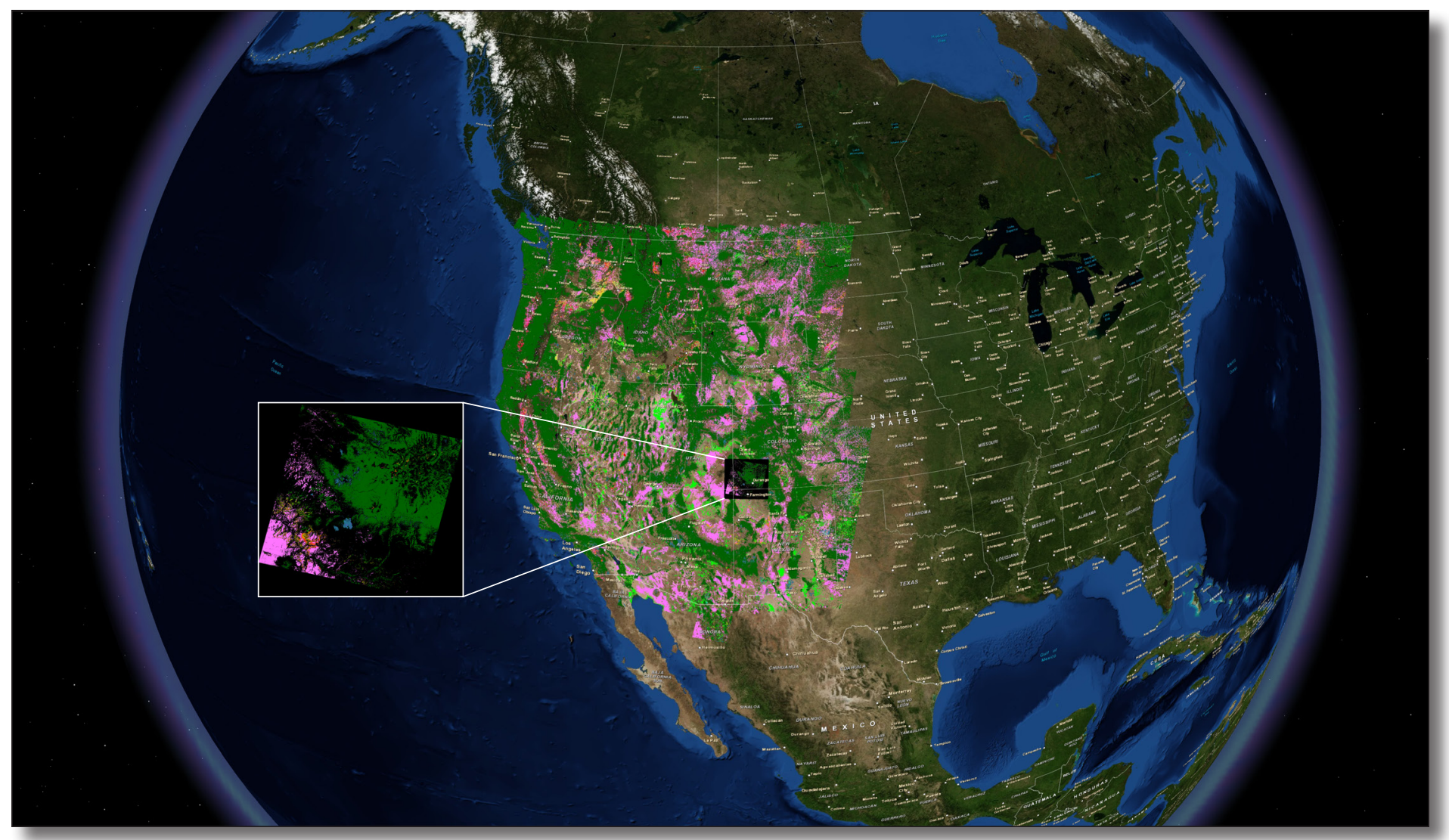

Scientific Investigations Map 3252 


\section{Automated Mapping of Mineral Groups and Green Vegetation from Landsat Thematic Mapper Imagery with an Example from the San Juan Mountains, Colorado}

By Barnaby W. Rockwell 


\title{
U.S. Department of the Interior SALLY JEWELL, Secretary
}

\section{U.S. Geological Survey Suzette M. Kimball, Acting Director}

\author{
U.S. Geological Survey, Reston, Virginia: 2013
}

For more information on the USGS - the Federal source for science about the Earth, its natural and living resources, natural hazards, and the environment, visit http://www.usgs.gov or call 1-888-ASK-USGS.

For an overview of USGS information products, including maps, imagery, and publications, visit http://www.usgs.gov/pubprod

To order this and other USGS information products, visit http://store.usgs.gov

Any use of trade, firm, or product names is for descriptive purposes only and does not imply endorsement by the U.S. Government.

Although this information product, for the most part, is in the public domain, it also may contain copyrighted materials as noted in the text. Permission to reproduce copyrighted items must be secured from the copyright owner.

Suggested citation:

Rockwell, B.W., 2013, Automated mapping of mineral groups and green vegetation from Landsat Thematic Mapper imagery with an example from the San Juan Mountains, Colorado: U.S. Geological Survey Scientific Investigations Map 3252, 25-p. pamphlet, 1 map sheet, scale 1:325,000, http://pubs.usgs.gov/sim/3252/. 


\section{Contents}

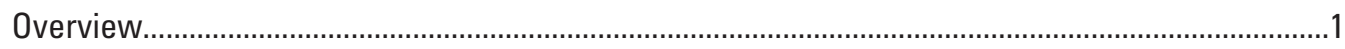

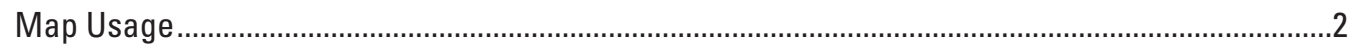

Descriptions of Map Sheet and Associated ERDAS IMAGINE Raster Image File Included

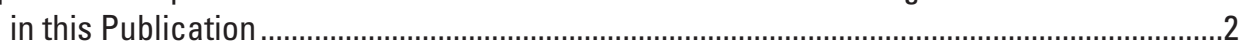

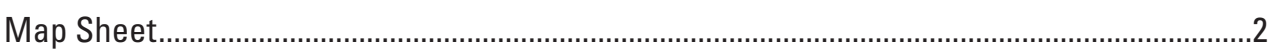

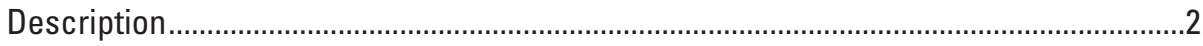

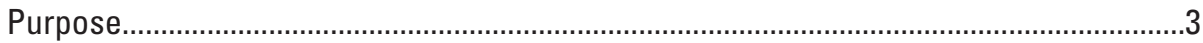

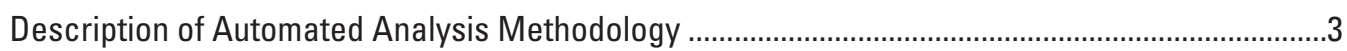

Mineral Group and Green Vegetation Indices .................................................................4

Image Processing for Masking and Index Thresholding ..............................................6

Modeling of Mineral Groups Through Boolean Combination of Index Results................8

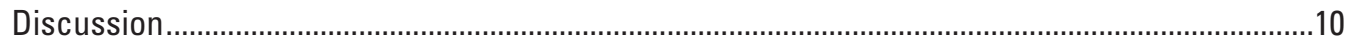

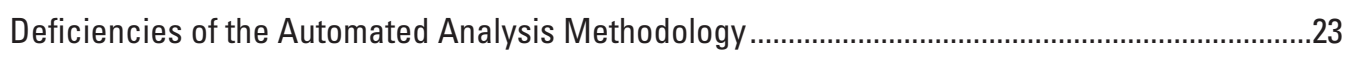

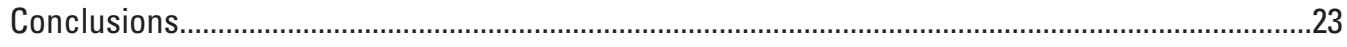

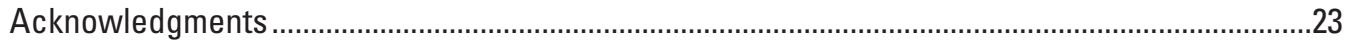

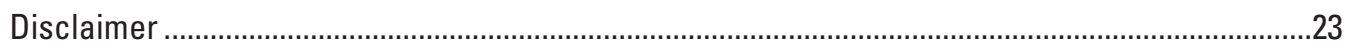

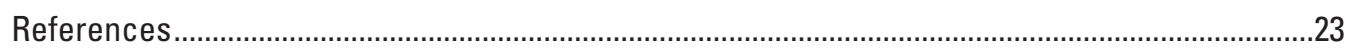

\section{Figures}

1. Plots of laboratory reference spectra (Clark and others, 2007) of iron-bearing minerals convolved to Landsat TM spectral resolution ........................................................5

2. Plots of laboratory reference spectra of alunite, pyrophyllite, and kaolinite (Clark and others, 2007) convolved to Landsat TM spectral resolution

3. Plots of laboratory reference spectra of vegetation (Clark and others, 2007) convolved to Landsat TM spectral resolution

4. Mineral group map of the Goldfield mining district, Nevada, generated from Landsat $7 \mathrm{ETM}+$ data using the automated algorithm described herein ...

5. Seamless map of mineral groups and green vegetation covering the western U.S. generated from Landsat 7 ETM+ data using the automated analysis algorithm described herein

6. A subset of the map sheet over the southern San Juan Mountains showing the mineral group map generated from Landsat 7 ETM+ data using the automated algorithm described herein...

7. Mineral group map of part of the Cuprite mining district, Nevada, generated from Landsat 7 ETM+ data using the automated algorithm described herein ..

8. Mineral group map of the Bingham Canyon mine, Oquirrh Mountains, Utah, generated from Landsat 7 ETM+ data using the automated algorithm described herein

9. Mineral group map of the Bodie Hills and surrounding region, California/Nevada generated from Landsat 7 ETM+ data using the automated algorithm described herein 
10. Mineral group map of the northern Marysvale volcanic field, Utah, generated from Landsat 7 ETM+ data using the automated algorithm described herein

11. One-meter-resolution imagery from the USGS The National Map Viewer ( http://raster.nationalmap.gov/ArcGIS/rest/services/TNM_Large_Scale_Imagery_ Overlay/MapServer) showing the Winkleman, Big Rock Candy Mountain, and Big Star replacement alunite deposits, Marysvale volcanic field, Utah

\section{Tables}

1. Generalized guide for preliminary interpretation of mineral group maps..........................2

2. Landsat 7 ETM + reflective spectral data characteristics (NASA, 2011) ............................3

3. Boolean logic used to combine Landsat 7 ratio-based index results into the single, classified map shown on mapsheet. Blank cells represent NOT operators. The first column indicates both the designated number (\#) of the output material class and the digital number (DN) of that class in the GIS-ready image file provided with this map. $\mathrm{X}=$ single index used to generate output material class

\section{Map}

Map of mineral groups and green vegetation derived from automated analysis of Landsat 7 enhanced thematic mapper plus satellite data: San Juan Mountains, Colorado and Four Corners Region

\section{Conversion Factors}

SI to Inch/Pound

\begin{tabular}{lcl}
\hline \multicolumn{1}{c}{ Multiply } & \multicolumn{1}{c}{ By } & \multicolumn{1}{c}{ To obtain } \\
\hline & Length & \\
\hline kilometer $(\mathrm{km})$ & 0.6214 & mile $(\mathrm{mi})$ \\
meter $(\mathrm{m})$ & 3.281 & foot $(\mathrm{ft})$ \\
micrometer $(\mu \mathrm{m})$ & 0.001 & millimeter $(\mathrm{mm})$ \\
\hline
\end{tabular}




\title{
Automated Mapping of Mineral Groups and Green Vegetation from Landsat Thematic Mapper Imagery with an Example from the San Juan Mountains, Colorado
}

\author{
By Barnaby W. Rockwell
}

\section{Overview}

Ongoing U.S. Geological Survey (USGS) national-scale mineral resource and geoenvironmental assessments require an efficient and accurate means of mapping and characterizing mineral exposures related to mined and unmined hydrother- $\square$ mally altered rocks and mine waste. The presence and miner- $\square$ alogy of altered rocks are important factors in determining the occurrence potential of concealed mineral deposits. Investiga- $\square$ tions at the deposit and watershed scales have described the importance of sulfide-bearing altered rocks and mine waste as diffuse sources of acidic solutions that can transport metals into the hydrologic system. These rocks and waste materials contain minerals that can be identified using spectral analysis of satellite remote sensing data. Analysis of multispectral data acquired by the Advanced Spaceborne Thermal Emission and Reflection Radiometer (ASTER, http://asterweb.jpl.nasa.gov/) sensor carried by the National Aeronautics and Space Admin-[ istration (NASA) Earth Observing System Terra satellite is currently being employed to generate mineral group maps over large areas of the United States (U.S.) and its territories in support of USGS assessment efforts (Rockwell, 2012).

Since the launch of the Landsat 4 satellite in 1982, the six bands of multispectral data collected by the Thematic Map- $\square$ per (TM) sensor have been used to identify and map mineral groups and other features on the Earth's surface. Although maps generated by such analysis are less detailed than those derived from analysis of the nine reflective bands of ASTER data, they are nevertheless useful in identifying hydrother- $\square$ mally altered rocks and mine waste bearing oxidizing sulfide minerals, and can be very efficiently produced at national scales. Landsat data are available at no cost worldwide, and one Landsat scene covers approximately the same area as nine ASTER scenes.

This report introduces a new methodology for the auto- $\square$ mated analysis of Landsat TM data that has been applied to more than 180 scenes covering the western United States. A map of mineral groups and green vegetation produced using this new methodology is presented that covers the western San Juan Mountains, Colorado, and the Four Corners Region. The map results can be compared to mineral and vegetation maps of the Silverton caldera region produced from analysis of Airborne Visible/Infrared Imaging Spectrometer (AVIRIS) data (Dalton and others, 2004; 2007) and ASTER data (Rockwell, 2012).

The map presented here was produced from one full scene of Landsat 7 Enhanced Thematic Mapper Plus (ETM+) data acquired on September 12, 2000. The ASTER data analyzed by Rockwell (2012) were acquired on the same day. The Landsat data were obtained from the USGS Earth Resources Observa- $\square$ tion and Science Center (EROS) in L1T orthorectified format. .

Digital mineral and vegetation mapping results are presented in GeoPDF and ERDAS IMAGINE format (.img). Georeferencing information is included in both file types. The TerraGo Toolbar (http://www.terragotech.com/products/] field-data-collection/terrago-toolbar/), a no-cost extension for Adobe Acrobat Reader, is required for viewing geographic coordinates in the GeoPDF files. With or without the toolbar, multiple, geographically referenced map layers can be turned on and off for viewing and printing. A map of hydrothermal alteration types, mineral groups, and green vegetation derived from automated analysis of ASTER data (Sheet 5 of Rockwell, 2012) is included in the GeoPDF file, as is the 1:500,000-scale geologic map of Colorado (Tweto, 1979; Green, 1992). The GeoPDF contains a bookmark that will download the ASTER- $\square$ derived mineral group map when clicked. Subsidiary map lay- $\square$ ers showing administrative boundaries, roads, surface hydrol-[ ogy, and landmarks (for example, National Parks) are also included. These layers are provided for user convenience and may not conform to USGS map standards. The layer of surface hydrology is scale-dependent, with smaller, lower-order water- $\square$ courses appearing when viewed at larger scales. The ERDAS-[ format file is suitable for integration with other geospatial data in Geographic Information Systems (GIS). The ERDAS file showing occurrence of mineral and vegetation groups identi- $\square$ fied using automated analysis has been attributed according to identified material, so that the color-coded material detected in a pixel can be queried with the interactive attribute identifica- $\square$ tion tools of GIS and image processing software packages (for example, the Identify Tool of ArcMap and the Inquire Cursor Tool of ERDAS IMAGINE). For the attribute information to appear in the ArcMap Table of Contents, open the ERDAS 
file in ArcMap and symbolize using Unique Values for the "Materialid" value field. Metadata compliant with Federal Geographic Data Committee (FGDC) standards have been included for the ERDAS-format file, and contain important information regarding geographic coordinate systems, attributes describing identified materials, and cross-references.

\section{Map Usage}

The image map was designed primarily for the regional mapping and characterization of exposed surface mineralogy, including that related to hydrothermal alteration and supergene weathering of pyritic rocks (Rockwell, 2012). As hydrolytic alteration commonly occurs along faults and fractures that serve as conduits for potentially metal-bearing fluids, the presence and type of alteration can provide important information for mineral resource investigations. Prospective areas for epithermal and porphyry-type mineralization in which alteration is identified are, in general, more likely to host near-surface deposits.

Pyrite is a common gangue mineral important for geoenvironmental studies that is associated with hydrothermal alteration and many types of ore deposits. Weathering of pyrite produces sulfuric acid upon exposure to atmospheric oxygen and water that can leach and transport potentially toxic metals into the groundwater system. Knowledge of pyrite occurrence and the extent and type of alteration is vital in developing predictive models of downstream surface water geochemistry in both mined and unmined catchments, and to evaluate pre- and post-mining effects of altered areas on local hydrology. Ferric iron minerals including jarosite, copiapite, melanterite, and goethite are also produced during the weathering process, and concentrations of undifferentiated ferric iron-bearing minerals can be identified using Landsat TM data. Mine waste and tailings in which no mineral groups are mapped are less likely to represent exposed, nonpoint sources of acidic solutions, or are too small in size to be mapped using Landsat data. The maps can also be used to evaluate mineral exposure at mine sites that have undergone remediation prior to the acquisition of the Landsat data. It is important to note that the Landsat-based mineral group mapping will preferentially identify potentially acid-producing assemblages over acid-neutralizing assemblages including carbonates and chlorite because of the weaker spectral absorption features related to the $\mathrm{CO}_{3}{ }^{2-}$ and $\mathrm{Mg}-\mathrm{OH}$ molecules at Landsat TM spectral resolution. Mineral group maps similar to those described herein and generated from the same Landsat scene were used in a GIS-based statistical analysis of the Silverton mining area in the San Juan Mountains that identified the variables influencing water quality (Yager and others, 2013).

The Landsat TM-derived mineral group map can be best interpreted in conjunction with geologic maps in a GIS environment. The character and origin of an identified mineral group occurrence can begin to be understood by recognizing the host rock lithology or material type (table 1). Most occurrences of known hydrothermal alteration contain the clay-sulfate-mica-marble mineral group, but a vast majority of the occurrences of all mineral groups are unrelated to alteration. Within volcanic rocks and mine waste, the presence of alteration and (or) supergene weathering of pyrite can be inferred if both ferric iron and the clay-sulfate-mica-marble mineral groups are present, especially in the same pixel. The maps may aid in delineating lithologic and alluvial units in which minerals identifiable using spectral remote sensing exist in abundance.

Table 1. Generalized guide for preliminary interpretation of mineral group maps.

\begin{tabular}{ll}
\hline $\begin{array}{c}\text { Host rock or } \\
\text { material type }\end{array}$ & \multicolumn{1}{c}{$\begin{array}{c}\text { Highest probability origin of } \\
\text { mineral group occurrence }\end{array}$} \\
\hline volcanic & hydrothermal alteration \\
plutonic & $\begin{array}{l}\text { lithology (commonly mica) or alteration } \\
\text { lithology (commonly mica and (or) clays), } \\
\text { diagenesis, or alteration (rare) }\end{array}$ \\
sedimentary & $\begin{array}{c}\text { lithology, weathering, metamorphic grade and } \\
\text { type, or alteration (rare) }\end{array}$ \\
metamorphic & weathering \\
alluvium & alteration and (or) supergene weathering of \\
mine waste & pyritic rocks \\
\hline
\end{tabular}

\section{Descriptions of Map Sheet and Associated ERDAS IMAGINE Raster Image File Included in this Publication}

\section{Map Sheet:}

Title:

MAP OF MINERAL GROUPS AND GREEN VEGETATION

DERIVED FROM AUTOMATED ANALYSIS OF LAND-

SAT 7 ENHANCED THEMATIC MAPPER PLUS SATEL-

LITE DATA: SAN JUAN MOUNTAINS, COLORADO AND

FOUR CORNERS REGION

Filename:

le70350342000256pac01.tar_msi_aa11_merge.img

\section{Description:}

This image shows the results of a new methodology designed for the automated identification and mapping of mineral groups and green vegetation from Landsat ETM+ data at regional to national scales. Detailed description of this 
methodology is provided in the following section. These results were modeled using Boolean algebra from the raw results of the ratio-based analysis algorithm. The 10 output classes are ordered relative to decreasing inferred acidproducing potential in non-sedimentary rocks (commonly referred to as net acid production, or NAP) from top to bottom. Note that although ferrous iron itself has little to no acid neutralizing capacity (ANC), it is often associated with chlorite-, epidote-, and (or) carbonate-bearing rocks that can have substantial ANC (Yager and others, 2008).

\section{Purpose:}

This image shows the occurrence of mineral groups and dense green vegetation. The image provides an easily interpretable tool for geologists, watershed modelers, and land managers engaged in geoenvironmental watershed modeling or mineral resource assessment at regional to national scales. The image has been attributed by pixel value with material identification data that can be queried in most image processing and GIS software packages. Metadata includes pixel values associated with each identified material.

\section{Description of Automated Analysis Methodology}

Landsat $7 \mathrm{ETM}+$ multispectral data consist of 6 bands measuring reflected electromagnetic energy (bands 1-5 and 7, $0.45-2.35 \mu \mathrm{m}$, table 2 ) and one band measuring emissive thermal infrared energy (band 6, 10.4-12.5 $\mu \mathrm{m}$ ) (NASA, 2011). Only the reflective bands were used for this study, and have a ground instantaneous field of view (GIFOV, or ground pixel size), of 30 meters. Band ratios, which highlight variation in reflectance between wavelength regions measured by the various bands, or channels, of the sensor, have been the simplest and most widely used analysis method applied to TM data (Crippen, 1989; Knepper, 1989, 2010; Rockwell, 1989).

Table 2. Landsat $7 \mathrm{ETM}+$ reflective spectral data characteristics (NASA, 2011).

$[\mu \mathrm{m}$, micrometer]

\begin{tabular}{cccl}
\hline Band & $\begin{array}{c}\text { Landsat 7 ETM+ } \\
\text { wavelength } \\
\text { range }(\boldsymbol{\mu m})\end{array}$ & $\begin{array}{c}\text { Landsat 7 ETM+ } \\
\text { band center } \\
(\boldsymbol{\mu m})\end{array}$ & Wavelength region \\
\hline 1 & $0.45-0.52$ & 0.485 & Blue \\
2 & $0.52-0.60$ & 0.560 & Green \\
3 & $0.63-0.69$ & 0.66 & Red \\
4 & $0.76-0.90$ & 0.83 & Near-infrared \\
5 & $1.55-1.75$ & 1.65 & Shortwave-infrared \\
7 & $2.08-2.35$ & 2.215 & Shortwave-infrared \\
\hline
\end{tabular}

To efficiently generate uniform maps of minerals and hydrothermal alteration over very large areas using Landsat TM data, automated processing and analysis techniques are required. As such, the analysis must accurately identify exposed minerals or mineral groups (minerals having similar spectral properties given the spectral resolution of the data being analyzed) from any suitable Landsat scene in any climate or terrain with no operator interaction. Suitable scenes are those with minimal cloud, haze, dust, smoke, and snow cover and maximal solar illumination (high solar elevation angle during late spring to early autumn).

In the northern hemisphere, scenes acquired in late May through early July are optimal to avoid the presence of senesced cheatgrass and other dry vegetation that are more abundant in mid-summer through autumn (Kokaly, 2011). Such dry vegetation typically has deep absorptions in the shortwave-infrared (SWIR) region caused by leaf biochemicals such as lignin and cellulose (Rockwell, 2009), and is spectrally similar at Landsat TM spectral resolution to minerals having strong SWIR (TM band 7) absorption features (Elvidge and Lyon, 1985; John and others, 2010). This spectral similarity of dry vegetation and many clay, sulfate, and mica minerals can lead to false identifications of this mineral group when Landsat scenes acquired in mid-July through October are analyzed, especially over areas in which cheatgrass is abundant, such as the northern Great Basin (northern Nevada and surrounding region).

The methodology presented here involves the use of compound band ratios to identify areas where one or more specific spectral absorption features are present. Ratios were developed to identify mineral groups based on diagnostic absorptions of pure and mixed mineral species in laboratory reference spectra convolved to Landsat TM spectral resolution. The technique assumes that only a particular mineral or mineral group (or green vegetation) will have deep absorption at a particular wavelength interval (one or more adjacent Landsat TM bands). If another surface material, material mixture, or feature has deep absorption at a given wavelength interval, a false detection of a mineral group having a similar absorption feature will occur. The utility of a ratio of type $(x+y) / z$ to identify absorption at band $\mathrm{z}$ relative to adjacent bands $\mathrm{x}$ and y was first demonstrated by Crowley and others (1989), who described the technique "relative band depth" mapping.

Prior to computing the material indices described below, the uneven edges of the Landsat TM bands were equalized by setting pixels to zero if that pixel had a digital number (DN) value of zero in any band in the raw data. To mitigate effects of Rayleigh (gaseous) scattering (Kaufman, 1989), a darktarget subtraction was applied in the form of:

$$
\begin{gathered}
\mathrm{DN}_{\text {haze }}=\left(\mathrm{DN}_{\text {raw }}+(\text { constant }-\right. \\
\text { (non-zero minimum value per band })))
\end{gathered}
$$

A constant value of five was used to offset values to avoid divisions by zero in the ratio-based analysis. Similar atmospheric corrections using dark-target subtraction are discussed by Chavez (1988) and Song and others (2001). 
All analytical processing described below was performed in one pass, producing the output file provided with this map. This processing takes 3 minutes per full Landsat $7 \mathrm{ETM}+$ scene on an Intel ${ }^{\circledR}$ Core $^{\mathrm{TM}}$ i7 Gulftown processor running at $3.7 \mathrm{GHz}$, including the computation of reducedresolution pyramid layers for fast display.

When analyzing large areas using many Landsat TM scenes, inter-scene variability can be reduced by converting the data to exoatmospheric, or "top of atmosphere (TOA)," reflectance (Chander and others, 2009). This process involves the radiometric calibration of the data to at-sensor spectral radiance followed by corrections for variance in exoatmospheric solar irradiance as a function of wavelength, earth-sun distance, and solar zenith angle. Such conversion is particularly useful when analyzing data from different sensors, for example Landsat 4, 5, and 7. Although TOA reflectance conversion has not provided significant advantages in generating seamless mineral group maps, future research will experiment with the incorporation of the conversion into the processing stream. Coverage of Landsat 7 ETM+ data acquired between 1999 and 2003 for which the Scan Line Corrector was functioning ("SLC-On") is excellent for the western U.S., so there has been no need to use data from other sensors to map that area. However, as work proceeds into the more temperate and alpine regions of the eastern U.S., Alaska, and Hawaii, the need to use data collected by the Landsat 4 and 5 sensors may arise, making TOA reflectance conversion more applicable and necessary.

\section{Mineral Group and Green Vegetation Indices}

Five ratio-based spectral indices were generated that exploit diagnostic absorption feature characteristics derived from published spectral libraries to highlight specific mineral groups. Information regarding the spectral and spatial characteristics of Landsat TM data is provided in table 2. In the formulas for the indices, Landsat TM (or ASTER) bands are indicated in bold.

1. Ferric iron 1 "redness" index

A Landsat TM 3/1 ratio was used to highlight areas that have absorption in Landsat band 1 (blue wavelengths) relative to band 3 (red wavelengths) (fig. 1). Ferric iron minerals are characterized by deep charge-transfer absorptions in the ultraviolet $(<0.4$ micrometers) (Clark, 1999). The long-wavelength edge of this absorption extends into the visible, absorbing blue and some green light and creating the characteristic red, orange, and yellow colors of such minerals. This ratio is similar to the ASTER 2/1 ratio described by Rockwell (2012), and is commonly used to highlight ferric iron minerals (Knepper, 1989, 2010; Rockwell, 1989).

Jarosite will generally have deeper absorption at band 1 compared to goethite (fig. 1); both minerals are common in weathered pyritic rocks. Most hematites will also show less band 1 absorption compared with jarosite. However, this index will highlight areas in which any ferric iron mineral (including jarosite, goethite, and hematite) occurs pervasively or as coatings. Ferric iron-bearing surfaces of hydrothermally altered rocks, sedimentary rocks such as red beds and arkoses, metamorphic rocks containing weathered, iron-bearing mafic minerals such as hornblende and biotite, sand deposits, and alluvium derived from such rocks will be identified with this index. The index is sensitive to ferric iron even in low concentrations.

\section{Ferric iron index 2}

A Landsat TM $(\mathbf{3} / \mathbf{1}) \times((\mathbf{3}+\mathbf{5}) / \mathbf{4})$ compound ratio was used to highlight ferric iron-bearing areas in which crystal-field absorptions in the near infrared (Landsat band 4) are present in addition to the charge transfer absorptions previously described (3/1 ratio). The index is similar to the ASTER $(\mathbf{2} / \mathbf{1}) \times(0.5 \times$ $((\mathbf{2}+\mathbf{4}) / \mathbf{3})$ ferric iron index described by Rockwell (2012). Figure 1 shows that the crystal-field absorptions in jarosite are significantly deeper than those of goethite, although the visible to near-infrared (VNIR) spectral characteristics of ferric iron minerals vary greatly relative to abundance and grain size (Rockwell, 2004). Since this ratio contains the 3/1 operator of ferric iron index 1, pixels with high index values will be well correlated with those of ferric iron index 1 . Ferric iron index 2 will identify areas in which ferric iron minerals are present in greater abundance than ferric iron index 1, and these areas will in most cases be surrounded by pixels highlighted by ferric iron index 1 .

3. Ferrous iron - coarse-grained ferric iron - fire ash index

Ferrous iron produces a broad VNIR absorption at Landsat bands 3 and 4 relative to 2 and 5 (fig. 1). A Landsat TM $(\mathbf{2}+\mathbf{5}) /(\mathbf{3}+\mathbf{4})$ compound ratio was used to highlight areas with this spectral shape, and is similar to the ASTER $(\mathbf{1}+\mathbf{4}) /(\mathbf{2}+\mathbf{3})$ ratio described by Rockwell (2012). In the Silverton caldera area, chlorite associated with propylitic alteration is the mineral most commonly identified using this index.

This index also highlights concentrations of coarsegrained ferric iron that are typically characterized by deep crystal-field absorption in band 4 relative to band 5 , as exhibited by the spectrum of hematite GDS27 in figure 1. Hematite-bearing oxidized basalts on cinder cones in young volcanic fields will typically be identified using this index. Coarsegrained goethite having deep and broad crystal-field absorptions near 1.0 micrometer (Rockwell, 2004) will also be highlighted. 


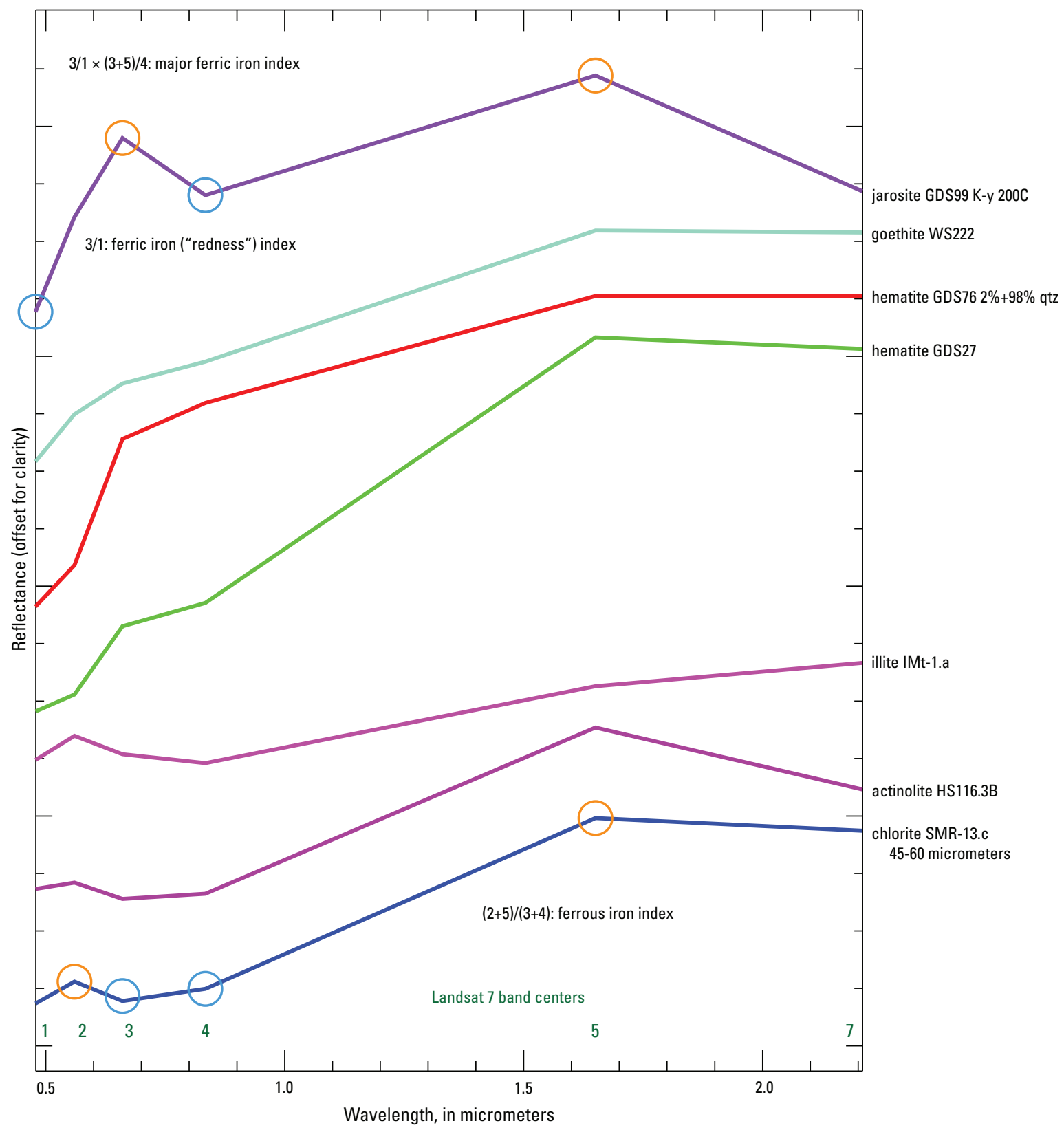

Figure 1. Plots of laboratory reference spectra (Clark and others, 2007) of iron-bearing minerals convolved to Landsat TM spectral resolution. Plots are annotated with circles indicating Landsat bands used in the material indices. Orange circles show bands used in the numerator of an index, and light blue circles show bands used in the denominator. Landsat band centers are shown along the bottom. See text for explanation. Click on figure for more detailed image.

The index can also be expected to highlight rocks having a general greenish color (for example, greenstones), blue-gray shales (including the Cretaceous Mancos Shale on map sheet), moist soils, and fire ash. The spectral properties of forest fire ash and its detection using AVIRIS data analysis are described by Kokaly and others (2006).
4. Clay-sulfate-mica-marble index

Deep absorption in the SWIR (Landsat TM band 7) relative to band 5 is characteristic of Al-OH- and (or) bound water-bearing phyllosilicates, sulfates, and amphiboles (fig. 2), and the Landsat 5/7 ratio is used to highlight this broad mineral group 
(Knepper, 1989, 2010; Rockwell, 1989). Carbonate minerals such as calcite and dolomite, Fe-OHbearing minerals such as epidote, and $\mathrm{Mg}-\mathrm{OH}-$ bearing phyllosilicate minerals such as chlorite, talc, and serpentine ("CEC" mineral group) have SWIR absorptions at slightly longer wavelengths that are only partially covered by the bandpass of Landsat band 7 (fig. 2 and table 1). As such, chlorite, epidote, and unaltered carbonate minerals typically have less band 7 absorption than clays, sulfates, and micas (fig. 2), and are not typically highlighted by the $5 / 7$ ratio. However, the ratio can readily detect carbonate minerals in marbles where recrystallization has concentrated the minerals and increased grain sizes, resulting in deeper absorption bands. Varieties of the Mg-OH phyllosilicate mineral serpentine can have a wide absorption feature near $2.33 \mu \mathrm{m}$ that can be highlighted by the $\mathbf{5 / 7}$ ratio, especially when the abundance of the mineral has been enriched by alteration and (or) metamorphic processes, typically in ultramafic rocks. As the carbonate absorption band of dolomite centered near $2.32 \mu \mathrm{m}$ lies at shorter wavelengths than the calcite band $(2.34 \mu \mathrm{m})$ and thus closer to the center of the Landsat TM band 7 bandpass (table 2), dolomitic marbles are slightly more likely to be identified using the 5/7 ratio. In areas where no phyllosilicates, sulfates, or amphiboles with deep band 7 absorption exist, the 5/7 ratio may highlight the CEC mineral group even in the absence of recrystallization or other enrichment.

As previously mentioned, dry vegetation has deep SWIR absorptions at Landsat TM band 7 related to lignin and cellulose that become more visible as leaf moisture decreases during senescence (fig. 3). Typical green, moist vegetation also shows absorption in band 7, in addition to high reflectance by mesophyll plant tissue in the near-infrared (TM band 4) and deep chlorophyll absorption in the visible red wavelengths (TM band 3). A Landsat $\mathbf{4} / \mathbf{3}$ ratio highlights areas of green vegetation with abundant chlorophyll content, similar to the ASTER $(\mathbf{1}+\mathbf{3}) / \mathbf{2}$ ratio described by Rockwell (2012), and is used to generate the green vegetation index described below. As these SWIR vegetation absorptions can be highlighted by the Landsat 5/7 ratio (Elvidge and Lyon, 1985), results of a Landsat $4 / 3$ ratio are subtracted from the $5 / 7$ ratio results to generate the clay-sulfate-mica-marble index. This technique will largely eliminate the influence of green vegetation in the $\mathbf{5 / 7}$ ratio results so that only the clay-sulfate-mica-marble mineral group is identified. Dense, dry vegetation with low chlorophyll content (such as senesced cheatgrass) will not be substantially affected by this technique, and will still be observed in the index results, necessitating the selection of Landsat scenes acquired during late spring and early summer when most vegetation is green and relatively moist.

An effect of this green vegetation suppression is that mineral group occurrences partially covered with green vegetation will be removed from the index results, focusing the results on those mineral exposures that are free of vegetation. Most occurrences of intense advanced argillic and argillic alteration, especially those with acidic surface runoff related to sulfide oxidation, are well exposed with little to no green vegetation cover. Carbonate-bearing rock and soil are more likely to support vegetative growth, and are thus more likely to be removed from the claysulfate-mica-marble index by the green vegetation suppression process, although carbonates (and minerals with Mg-OH SWIR absorptions) are less likely to be detected by the index as described above.

\section{Green vegetation index}

A Landsat $\mathbf{4} / \mathbf{3}$ ratio is used to highlight areas with strong absorption in the red wavelengths (band 3) relative to band 4. Chlorophyll-related absorptions in green vegetation are the most common source of such absorption (fig. 3).

\section{Image Processing for Masking and Index Thresholding}

\section{Dark Area Masking}

Landsat ratio results can be spurious in areas of low surface albedo, including those with poor solar illumination caused by terrain shadow (Knepper, 2010). Such areas are masked from analysis using thresholds of Landsat TM band 5 determined through examination of many scenes from different climates, land cover, and terrain relief. Any pixel with a raw band $5 \mathrm{DN}$ value less than 80 is removed from all index results other than the green vegetation index.

\section{Water Masking}

A Landsat TM 1/5 ratio is used to highlight areas having a steep decrease in reflectance between the green and SWIR wavelengths. Water and snow are characterized by intense absorption in the SWIR relative to the visible spectral regions. A threshold value for the ratio was chosen based on examination of standing water in many Landsat scenes. A mask is created by applying the threshold to the $\mathbf{1 / 5}$ ratio result. The mask is then applied to index results other than the green vegetation index to remove data from areas of snow and standing water. Turbid water, shallow water with a bright substrate, and 


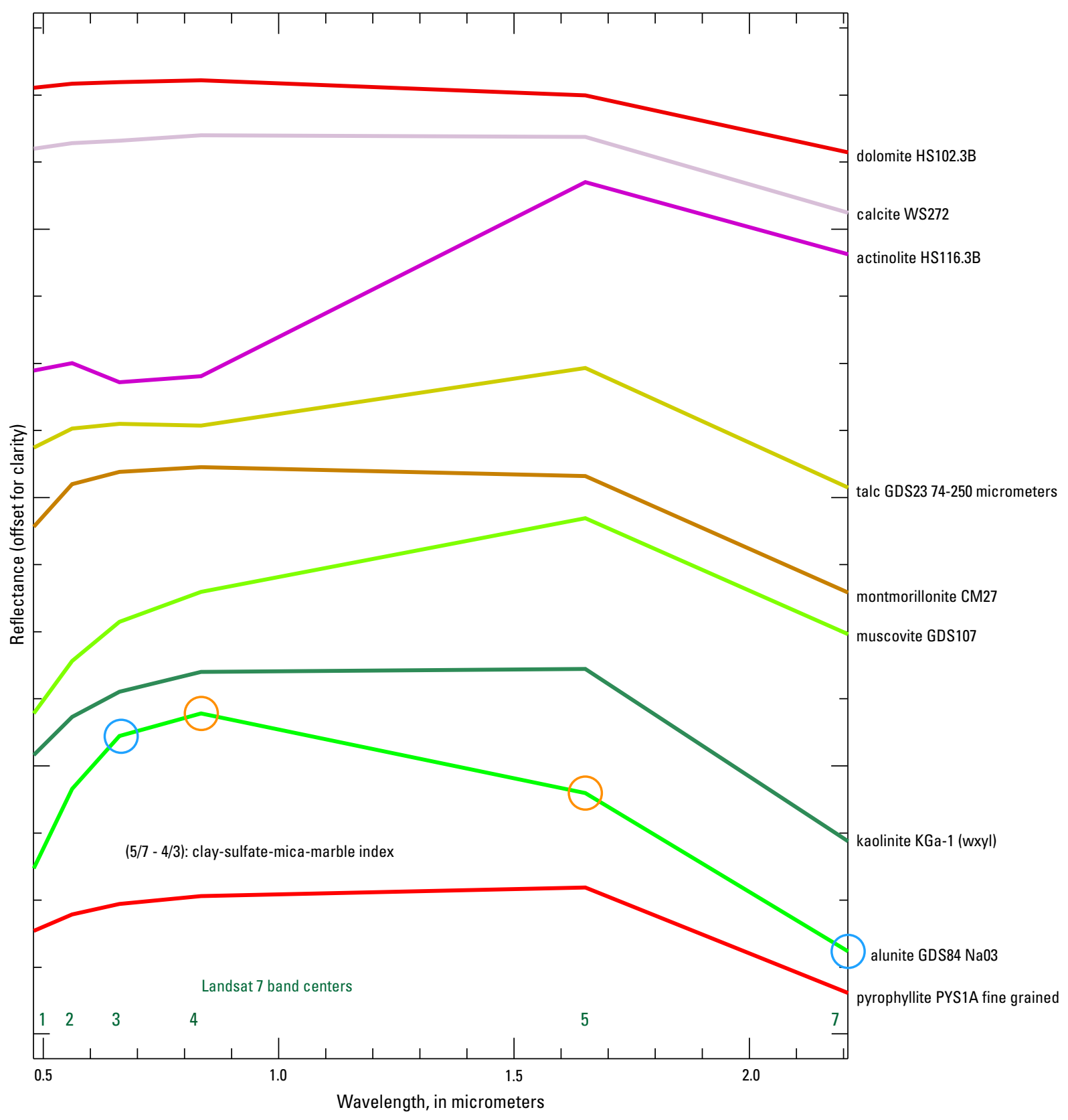

Figure 2. Plots of laboratory reference spectra of alunite, pyrophyllite, and kaolinite (Clark and others, 2007) convolved to Landsat TM spectral resolution. Plots are annotated with circles indicating Landsat TM bands used in the claysulfate-mica-marble index. Orange circles show bands used in the numerator of an index, and light blue circles show bands used in the denominator. Landsat band centers are shown along the bottom. See text for explanation. Click on figure for more detailed image.

mixtures of thin or melting snow and vegetation have reduced absorption in the SWIR and may not be entirely removed by this masking process.

3. Final index thresholding and clipping

The final indices are created by isolating the highest values using a common standard deviation threshold, followed by an index-specific clip (removal) of the lowest index values based on extensive testing of scenes from a variety of climates, underlying bedrock and surficial geology, terrain relief, and alteration types. These clips are minor in scope, and were determined based on detailed comparisons of the index results to mineral maps created from spectroscopic analysis of ASTER and AVIRIS imagery. The amount of low-end index values that are 


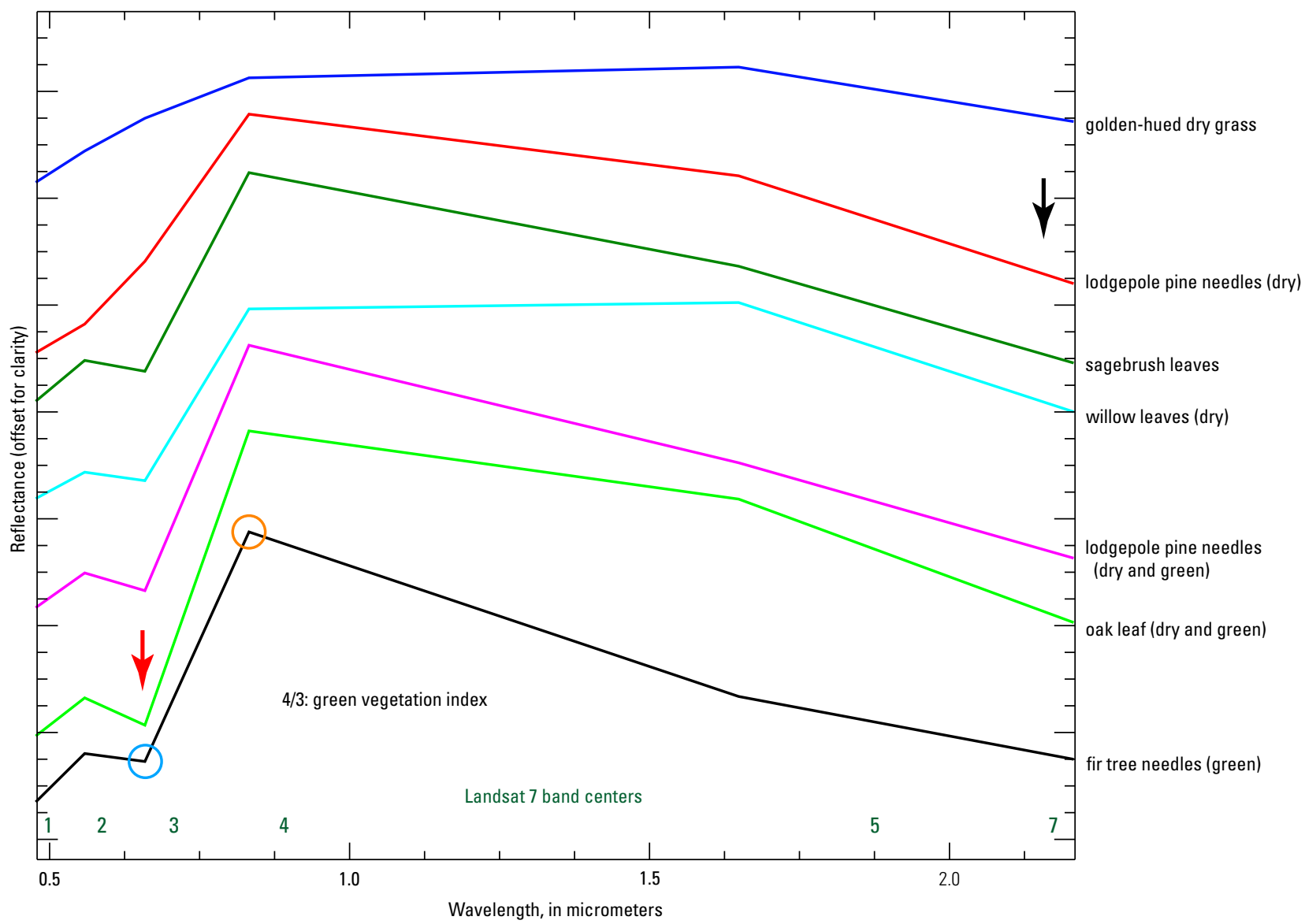

Figure 3. Plots of laboratory reference spectra of vegetation (Clark and others, 2007) convolved to Landsat TM spectral resolution. Spectra are ordered from bottom to top relative to decreasing depth of the chlorophyll absorption feature at Landsat TM band 3. Red arrow shows position of this chlorophyll absorption, and black arrow shows position of SWIR absorption related to lignin-cellulose and (or) leaf moisture. Although chlorophyll content decreases and dryness increases from bottom to top, absorption in band 7 is variable because of changes in lignin-cellulose content by species, moisture content, and sample characteristics. Plot at bottom is annotated with circles indicating Landsat TM bands used in the green vegetation index. Orange circle shows band used in the index numerator, and light blue circle shows band used in the denominator. Landsat band centers are shown along the bottom. Click on figure for more detailed image.

removed increases in the following order from low to high: (1) ferric iron index 2, (2) ferric iron index 1 and green vegetation, (3) clay-sulfate-mica-marble, and (4) ferrous iron - oxidized basalt - fire ash. The relatively high degrees of clipping of the latter two indices reflect a lower degree of confidence in the accuracies of results given the spectral similarities between these mineral groups and other surface features at Landsat TM spectral resolution. Increased clipping of low-end values will result in fewer detected pixels in an index, and increased confidence in those that remain. However, occurrences of the particular mineral group in lower abundance will be removed, which will focus the results on outcrops rather than distal alluvium derived from those outcrops.

Figure 4 shows a subset from the regional, Landsat-based mineral group mapping over the Goldfield mining district in west-central Nevada. As discussed by Rockwell
(2012) regarding the automated analysis of ASTER data, the clipping of the clay-sulfate-mica-marble index removes most of the alunite-bearing alluvium weathering southeastwards toward Stonewall Flat in which alunite (and kaolinite) are present in less abundance than in the intensely altered rocks from which the alluvium is derived.

\section{Modeling of Mineral Groups Through Boolean Combination of Index Results}

For the purposes of combining the five indices into a more easily visualized single map and assigning GIS-ready descriptive attributes, Boolean algebra was used to examine pixel occurrence in one or more indices and generate 10 output classes of mineral groups and green vegetation (map sheet). Table 3 shows the logic of the algebraic expressions. 


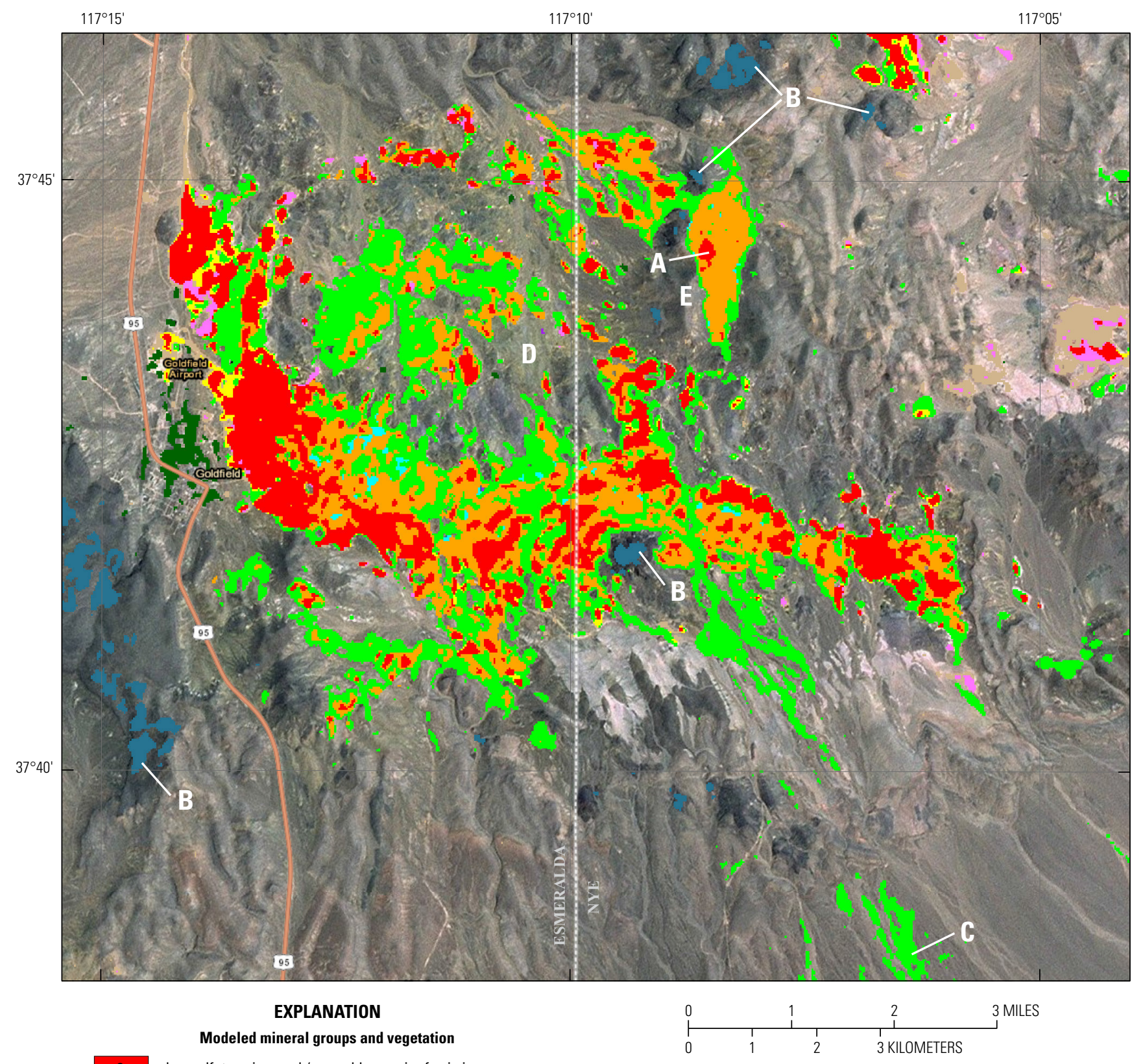

\begin{tabular}{|c|c|}
\hline 9 & clay, sulfate, mica, and /or marble + major ferric iron \\
\hline 8 & clay, sulfate, mica, and/or marble+ moderate to major ferric iron \\
\hline 7 & clay, sulfate, mica, and/or marble + minor ferric iron \\
\hline 3 & major feric iron \\
\hline 1 & major ferric iron (high redness) \\
\hline 5 & ferric + ferrous iron \\
\hline 6 & clay, sulfate, mica, and/or marble \\
\hline 10 & clay, sulfate, mica, and/or marble + ferrous iron \\
\hline 4 & $\begin{array}{l}\text { ferrous or course-grained ferric iron (may include oxidized } \\
\text { basalts, fire ash, some moist soils, and any blue/green rocks) }\end{array}$ \\
\hline 11 & dense, green vegetation \\
\hline
\end{tabular}

Figure 4. Mineral group map of the Goldfield mining district, Nevada, generated from Landsat 7 ETM+ data using the automated algorithm described herein. A, exposure of spectrally pure jarosite (Rockwell, 2012) identified as class 9; $B$, hematitebearing, oxidized Tertiary basalts mapped as class 4 ; $C$, alluvium containing alunite and kaolinite derived from weathering of intense advanced argillic alteration in the Goldfield Hills east of the town of Goldfield. Only alluvium in which the alteration minerals are present in highest abundance is shown, as most of the alluvium has been removed by the automated clipping process. The full extent of the alluvium is shown by Rockwell (2012); D, weakly propylitized rhyolite and quartz latite flows containing muscovite and chlorite in which the Landsat data analysis identified only sparse exposures of mineral groups, although several pixels of class 5 (ferric + ferrous iron) are present, representing abundant chlorite; E, Diamond (Peak). Click on figure for more detailed image. 
Table 3. Boolean logic used to combine Landsat 7 ratio-based index results into the single, classified map shown on mapsheet. Blank cells represent NOT operators. The first column indicates both the designated number (\#) of the output material class and the digital number (DN) of that class in the GIS-ready image file provided with this map. $X=$ single index used to generate output material class.

\begin{tabular}{|c|c|c|c|c|c|c|c|}
\hline \multirow{2}{*}{$\begin{array}{l}\text { Output Class } \\
\text { \# and DN } \\
\text { Value }\end{array}$} & \multirow{2}{*}{ Class Color } & \multirow{2}{*}{$\begin{array}{c}\text { Class Name } \\
\text { (Materialid attribute) }\end{array}$} & \multicolumn{5}{|c|}{ Material Index } \\
\hline & & & $3 / 1$ & $3 / 1 \times(3+5) / 4$ & $(2+5) /(3+4)$ & $5 / 7-4 / 3$ & $4 / 3$ \\
\hline 1 & light brown & minor ferric iron (high redness) & $\mathrm{X}$ & & & & \\
\hline 3 & magenta & major ferric iron & AND & AND & & & \\
\hline 4 & dark cyan & $\begin{array}{l}\text { ferrous iron or oxidized basalts (may } \\
\text { include any blue-green rocks, fire } \\
\text { ash, and some moist soils) }\end{array}$ & & & $\mathrm{X}$ & & \\
\hline 5 & purple & ferric + ferrous iron & $\mathrm{AND} / \mathrm{NOT}$ & AND & AND & & \\
\hline 6 & green & clay, sulfate, mica, and (or) marble & & & & $\mathrm{X}$ & \\
\hline 10 & cyan & $\begin{array}{l}\text { clay, sulfate, mica, and (or) marble }+ \\
\text { ferrous iron }\end{array}$ & & & AND & AND & \\
\hline 9 & red & $\begin{array}{l}\text { clay, sulfate, mica, and (or) marble }+ \\
\text { major ferric iron }\end{array}$ & AND & AND & AND/NOT & AND & \\
\hline 11 & dark green & dense, green vegetation & & & & & $\mathrm{X}$ \\
\hline
\end{tabular}

\section{Discussion}

As a means of validating the results of the automated analysis methodology, derived mineral group maps of several well-known mineralized and (or) hydrothermally altered areas in the western United States are presented for comparison with field-verified maps generated from detailed spectroscopic analysis of AVIRIS and (or) ASTER data (Rockwell, 2012). These maps are subsets of a seamless mineral group map of the southwestern U.S. (fig. 5).

Pixels in which both ferric iron indices and the clay-sulfate-mica-marble index occur are assigned the color red on the map sheet (output class 9 in table 3). Most advanced argillic, argillic, and phyllic alteration within volcanic rocks in the Silverton caldera area, (Bove and others, 2007; Rockwell, 2012) have been identified with this output class, as the high-sulfidation, magmatic-hydrothermal advanced argillic and phyllic alteration typically contain abundant pyrite that weathers to ferric iron minerals. The hydroxyl-bearing iron sulfate mineral jarosite, a relatively insoluble product of pyrite oxidation, has strong visible-near-infrared (VNIR) absorptions related to ferric iron in addition to deep Fe-OH absorption in the SWIR (fig. 1). As such, spectrally pure jarosite will be highlighted in the ferric iron and clay-sulfate-mica-marble indices if present in sufficient abundance and areal extent to be detected in a 30-m Landsat ETM+ pixel. Occurrences of jarosite + sericite on Rolling Mountain $15 \mathrm{~km}$ west-southwest of the town of
Silverton identified using AVIRIS (Dalton and others, 2004) and ASTER (Rockwell, 2012) data were mapped as output class 9 (map sheet). A small area of spectrally pure jarosite surrounded by alunite located east of Diamond (Peak) in the Goldfield mining district, Nevada, identified using AVIRIS and ASTER data (Rockwell, 2012) was identified as class 9 using the Landsat analysis algorithm presented here (fig. 4).

Large scars from wildfires, including those in the Mesa Verde area southwest of Mancos, have been identified primarily as class 4 because of VNIR absorptions of ash (map sheet). Ferric iron minerals were detected across large areas in the southwestern part of the Landsat scene within Quaternary eolian dune sands and silts, and Peoria Loess (unit Qe of Green, 1992 and Tweto, 1979), the Cretaceous Dakota Sandstone and Burro Canyon Formation (unit $\mathrm{Kdb}$ ), and locally within the Cretaceous Mancos Shale (Km, including Mesaverde Group or Formation, Frontier Sandstone and Mowry Shale), and shales and siltstones of the Jurassic Morrison Formation, Summerville Formation, and Entrada Sandstone (Jmse). In Arizona, ferric iron minerals mapped within the red-colored Wingate and red to buff Navajo Sandstones (Jurassic).

Mineral exposures related to alteration and (or) lithology were identified within quartzites, slates, and phyllites of the Proterozoic Uncompahgre Formation on Peaks One, Two, and Three and White Dome between the Grenadier Range and Elk Creek $15 \mathrm{~km}$ southeast of Silverton (A, fig. 6). The Landsat TM-based mapping identified mineral groups 6, 8, and 9, and 


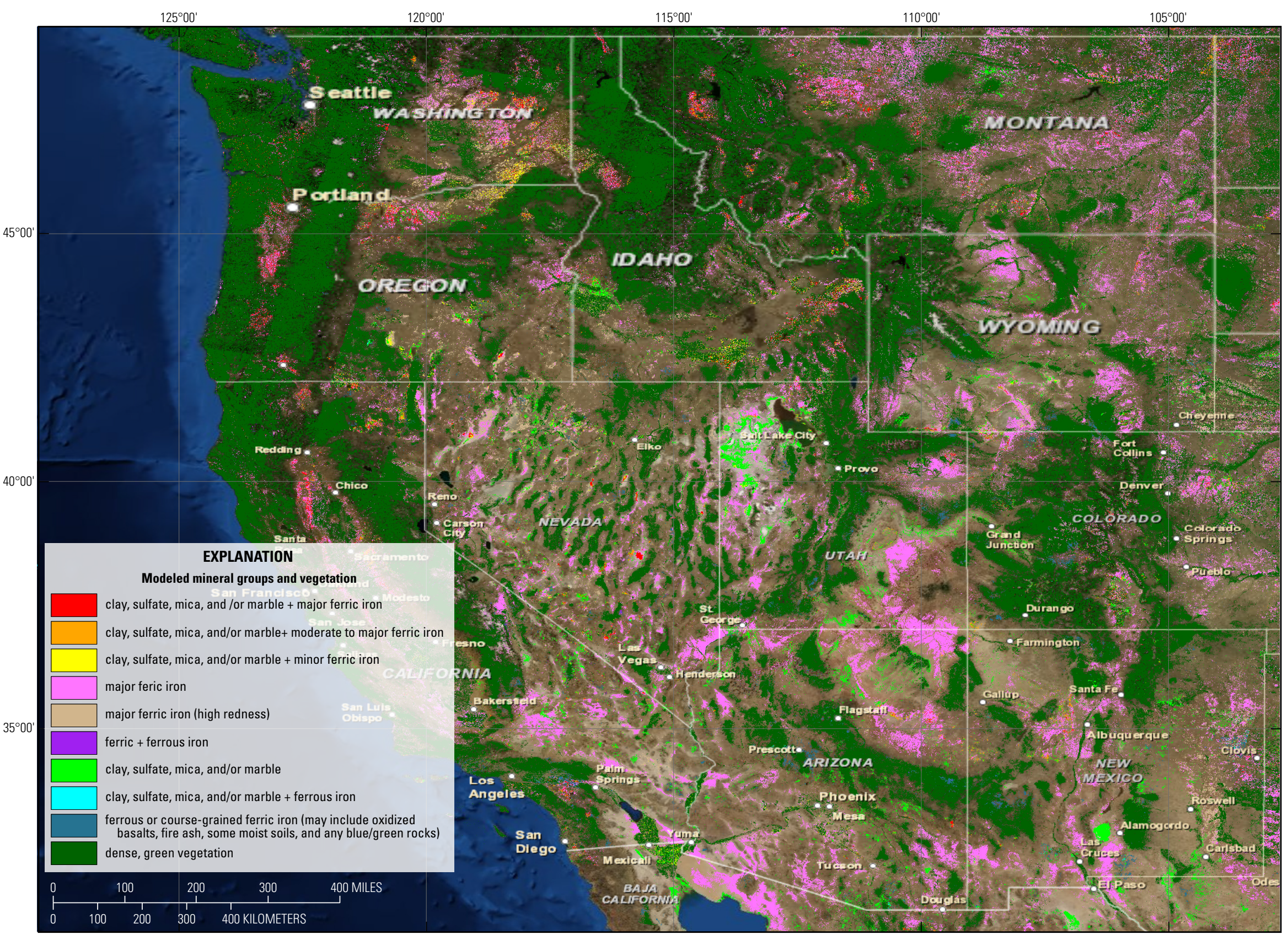

Figure 5. Seamless map of mineral groups and green vegetation covering the western U.S. generated from Landsat 7 ETM+ data using the automated analysis algorithm described herein. Click on figure for more detailed image. 
the ASTER-based mapping of Rockwell (2012) identified primarily ferric iron minerals and sericite with local kaolinite + sericite and kaolinite. While the sericite is most likely lithologic in character, representing primary or authigenic mica in the quartzite groundmass or phyllites, the presence of clay minerals in localized areas within the formation suggest the presence of fracture-controlled argillic hydrothermal alteration. The mineral mapping results in this area have not been field verified.

The Landsat TM-based mapping identified class 4 (ferrous iron) in Proterozoic felsic and hornblendic gneisses, metabasalts, and metatuff (unit Xfh of Green, 1992) mainly derived from low-grade metamorphism of volcanic rocks (B, fig. 6). ASTER-based mapping identified extensive exposures of calcite, chlorite, and possibly epidote in this area, often mixed with sericite or smectite. The ferrous iron mineral group identified by the Landsat TM mapping likely reflects the presence of chlorite, but the carbonate and $\mathrm{Mg}-\mathrm{OH}$ SWIR absorptions of calcite and chlorite are too weak to be detected by the Landsat analysis, as discussed above. Chlorite and mixed-layer chlorite/smectite are common in low-grade metabasalts; epidote will appear at higher metamorphic grades (Robinson and others, 1993).

Steam-heated alunite formed in near-surface environments from neutral-pH fluids derived from oxidation of $\mathrm{H}_{2} \mathrm{~S}$ typically does not contain pyrite (Rockwell and others, 2006). Such alteration should map as classes 6 or 7 (table 3), in which the clay-sulfate-mica-marble mineral group is abundant, but ferric iron derived from pyrite oxidation is present in low abundance, or not at all. Figure 7 shows a mineral group map of part of the Cuprite mining district, Nevada, in which steam-heated alunite without significant ferric iron minerals have been mapped as classes 6 and 7 (green and yellow, respectively). Maps produced from spectroscopic analysis of AVIRIS data (Rockwell, 2012) confirm that these areas consist of alunite + kaolinite with sparse to absent ferric iron minerals. Hematite may co-occur with and (or) overlie the steam-heated alunite, and wall rocks surrounding or underlying the alunite may contain abundant pyrite, which will weather to jarosite and (or) goethite. Alunitic rocks and alluvium in which hematite, jarosite, or goethite are present mapped as classes 8 or 9 in figure 7.

In typical pyritic rocks undergoing supergene alteration related to weathering, clay minerals such as kaolinite and smectite are produced from the breakdown of feldspars in the rocks, in addition to abundant ferric iron minerals (for example alunogen, copiapite, melanterite, jarosite, goethite; Cunningham and others, 2005). Such clays will tend to mask the $\mathrm{Fe}-\mathrm{OH}$ absorption feature of jarosite in TM band 7 (Rockwell and others, 2005), yet the clays themselves will be identified by the clay-sulfate-mica-marble index if present in sufficient abundance and areal extent. Weathered, pyritic mine waste and tailings with abundant supergene weathering products will typically be identified as class 9 . Waste and unmined, pyritic rock with weak or absent clay minerals, micas, or spectrally pure jarosite will typically map as ferric iron alone (classes 1 or 3). Figure 8 shows the weathered, highly pyritic waste rock along the east flank of the open pit at the Bingham Canyon porphyry-copper mine in Utah mapped as class 9.

The Landsat-based analysis methodology is capable of delineating most zones of intense advanced argillic, argillic, and phyllic alteration. Figure 9 shows a map of the Bodie Hills and surrounding area just north of Mono Lake, California, and can be compared to mineral maps of the area generated from spectroscopic analysis of ASTER data (Rockwell, 2010). Zones of intense quartz-alunite-kandite alteration along Red Wash (A1, fig. 9), a west-northwest-trending fault zone north of the Ramona mining district in the Wassuk Range (A2, fig. 9), and in an altered rhyolite plug $3 \mathrm{~km}$ west of the Aurora mining district (A3, fig. 9) are clearly seen, although the claysulfate-mica-marble mineral group is identified only where alunite and clay minerals are most abundant. In altered areas where alunite and clay minerals are less spectrally abundant and ferric iron minerals are also present, only the ferric iron mineral group is identified (A4, fig, 9). The lower spectral abundance of the clay-sulfate-mica-marble mineral group in these areas is controlled by less intense argillization and (or) the small size of more fracture-controlled zones relative to the 30-m GIFOV of a Landsat 7 ETM+ pixel. In smaller zones, areal mixing with unaltered rocks, soils, or vegetation in adjacent pixels will decrease the value of the 5/7 ratio and make removal of such pixels from the clay-sulfate-mica-marble index by the automated clipping process more likely.

The degree of correlation between mineral and mineral group mapping derived from analysis of ASTER and Landsat TM data over some extensively altered areas of the Marysvale volcanic field in Utah is shown in figure 10. Most altered areas and mill tailings mapped using AVIRIS (Rockwell and others, 2005; 2006) and ASTER (Rockwell, 2009) data were identified as classes $1,3,6,8$, or 9 . Altered rocks of the Winkleman replacement alunite deposit in the foothills of the Tushar Mountains $2 \mathrm{~km}$ west of Big Rock Candy Mountain were not mapped by the Landsat data analysis. The Winkleman area lies at an elevation 215-315 meters higher than the alteration in the Antelope Range, and therefore receives greater precipitation, resulting in thicker stands of vegetation (fig. 11). The use of the Landsat $4 / 3$ ratio for vegetation suppression removed pixels from the clay-sulfate-mica-marble index in this area. The automated analysis of ASTER data (Rockwell, 2012) did detect advanced argillic alteration in the Winkleman area.

Other than thick alluvial deposits along the west bank of the Sevier River derived from weathering of intense alunitic alteration on Alunite Ridge and Deer Trail Mountain (H, fig. 10), most alluvium containing alunite and kaolinite were not mapped, focusing the user on altered rock outcrops. 


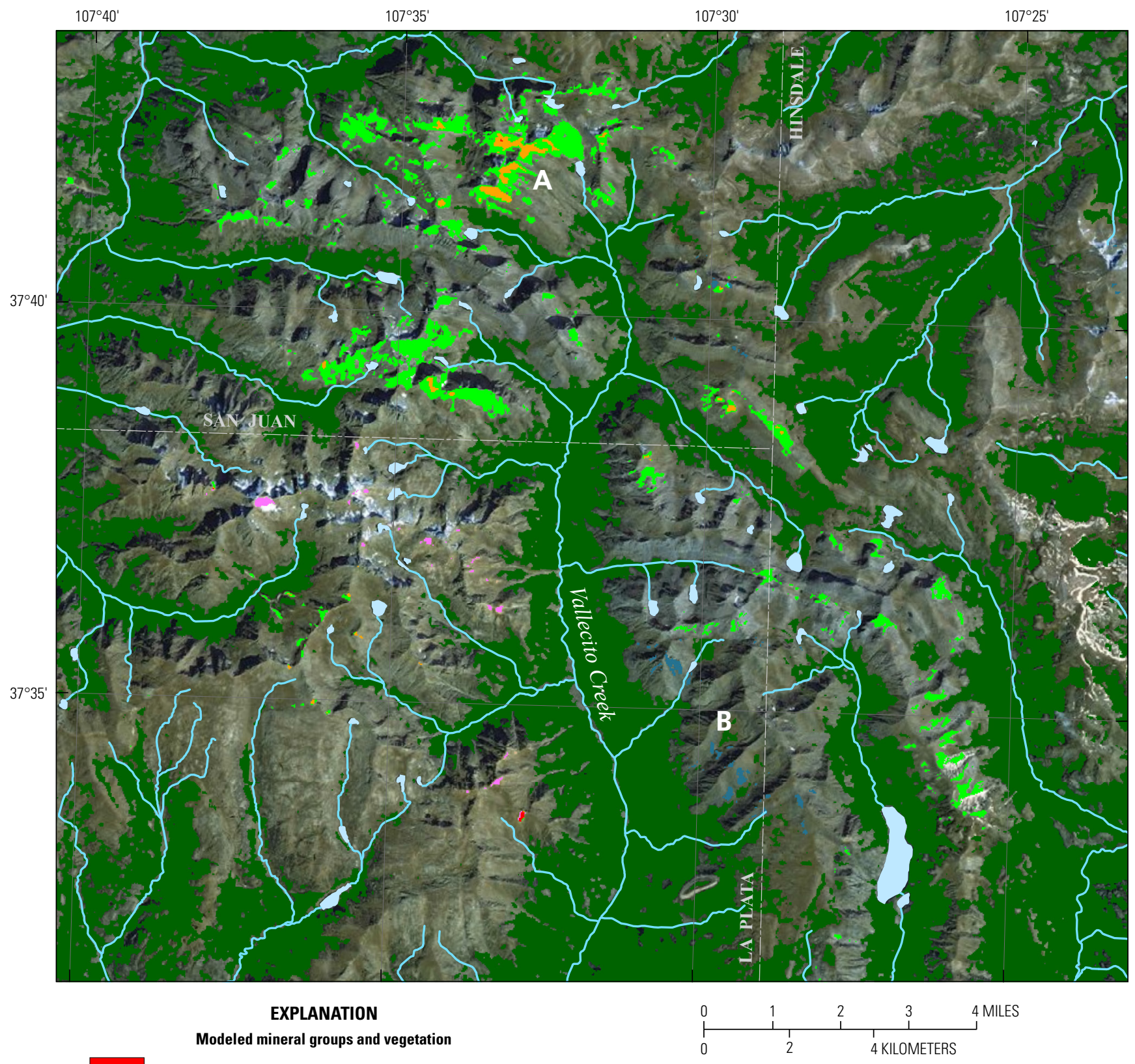

\begin{tabular}{|c|c|}
\hline 9 & clay, sulfate, mica, and /or marble + major ferric iron \\
\hline 8 & clay, sulfate, mica, and/or marble+ moderate to major ferric iron \\
\hline 7 & clay, sulfate, mica, and/or marble + minor ferric iron \\
\hline 3 & major feric iron \\
\hline 1 & major ferric iron (high redness) \\
\hline 5 & ferric + ferrous iron \\
\hline 6 & clay, sulfate, mica, and/or marble \\
\hline 10 & clay, sulfate, mica, and/or marble + ferrous iron \\
\hline 4 & $\begin{array}{l}\text { ferrous or course-grained ferric iron (may include oxidized } \\
\text { basalts, fire ash, some moist soils, and any blue/green rocks) }\end{array}$ \\
\hline 11 & dense, green vegetation \\
\hline
\end{tabular}

Figure 6. A subset of the map sheet over the southern San Juan Mountains showing the mineral group map generated from Landsat 7 ETM+ data using the automated algorithm described herein. Embedded digital layers include a 1:500,000scale geologic map (Green, 1992), two ASTER-derived mineral maps (Rockwell, 2012), and various geographic basemaps (ESRI, 2012). A, possible argillic alteration in metamorphosed quartzites and metapelites of the Uncompahgre Fm; B, ferrous iron (most likely from chlorite) identified in primarily metavolcanic rocks. Like the map sheet, the high-resolution version of this figure is a GeoPDF file containing multiple layers that can be visualized using the TerraGo ${ }^{\circledR}$ Toolbar plugin for Adobe Acrobat Reader. Click on figure for more detailed image. 


\section{Automated Mapping of Mineral Groups and Green Vegetation from Landsat Thematic Mapper Imagery}

Figure 7 (following page). Mineral group map of part of the Cuprite mining district, Nevada, generated from Landsat 7 ETM+ data using the automated algorithm described herein. A, alunite (+/- kaolinite) containing hematite (or local goethite) mapped as class 9 ; $B$, alunite and kaolinite in which ferric iron is absent or present in only low abundance, mapped as classes 6 or $7 ; \mathrm{C}$, green phyllitic siltstones of the Lower Cambrian Harkless Formation bearing chlorite and muscovite mapped as ferrous iron (class 4 , from chlorite) +/- clay-sulfate-mica-marble (class 10). Class 5 (ferric + ferrous iron) was mapped immediately to the east where the Harkless Fm is adjacent to ferric-iron bearing argillically altered rocks; D, Mule Spring Limestone in which the clay-sulfatemica-marble mineral group was not mapped; E, Stonewall Playa surface containing montmorillonite + goethite (Rockwell, 2012), mapped as major ferric iron (class 3 ) surrounded by minor ferric iron (class 1). Low-abundance montmorillonite was not identified because of automated index clipping. Like the map sheet, the high-resolution version of this figure is a GeoPDF file containing multiple layers that can be visualized using the TerraGo® Toolbar plugin for Adobe Acrobat Reader. Click on figure for more detailed image. 


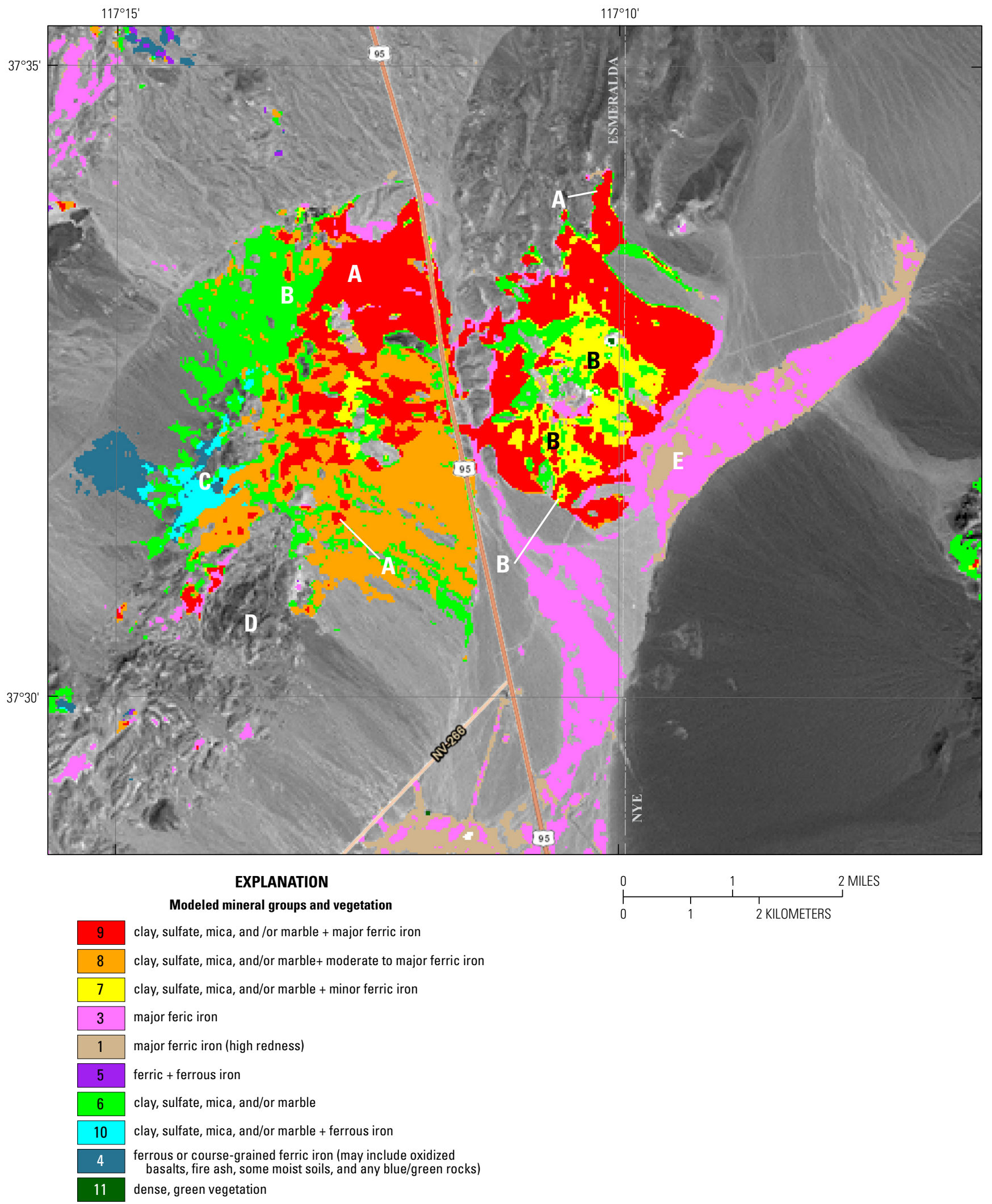


Figure 8 (following page). Mineral group map of the Bingham Canyon mine, Oquirrh Mountains, Utah, generated from Landsat 7 ETM+ data using the automated algorithm described herein. A, open mine pit in which micas, biotite, and ferrous iron minerals associated with potassic alteration in freshly exposed rocks (Rockwell and others, 2005) have not been mapped because of 1) poor solar illumination, and (or) 2) associated absorption features are weak because of low mineral abundance and other factors, and thus identified mineral groups have been removed by the automated index clipping. Most phyllic alteration lies on the fringes of the pit distal to the potassically altered core of the deposit; B, site of remediated International Smelter; C, barren, iron-bearing surfaces denuded by historic acidic emissions from the smelter (Rockwell and others, 2005); D, talc in wall rock in which no mineral groups were identified, indicating the weaker band depth of $\mathrm{Mg}-\mathrm{OH}$ SWIR absorptions compared to those of micas and clays in this area; $E$, highly pyritic waste rock containing locally abundant jarosite; $F$, waste and wall rock bearing clays, micas, and ferric iron minerals not mapped because of north-facing aspect and associated poor solar illumination; $G$, alluvial soils bearing ferric iron minerals derived from in-situ weathering of iron-bearing minerals and (or) deflation of weathered pyritic waste from mine site; $\mathrm{H}$, argillic alteration and ferric iron associated with Barneys Canyon and Melco distaldisseminated gold deposits. AVIRIS-derived mineral maps of the area (Rockwell and others, 2005) are available for comparison at these links: iron-bearing minerals, http://pubs.usgs.gov/ sir/2004/5241/graphics/f35.pdf, clay, sulfate, mica, $\mathrm{Mg}-\mathrm{OH}$, and carbonate minerals, http://pubs.usgs.gov/sir/2004/5241/graphics/ f36.pdf. Background image is from ESRI World Imagery base layer (ESRI, 2012). Click on figure for more detailed image. 


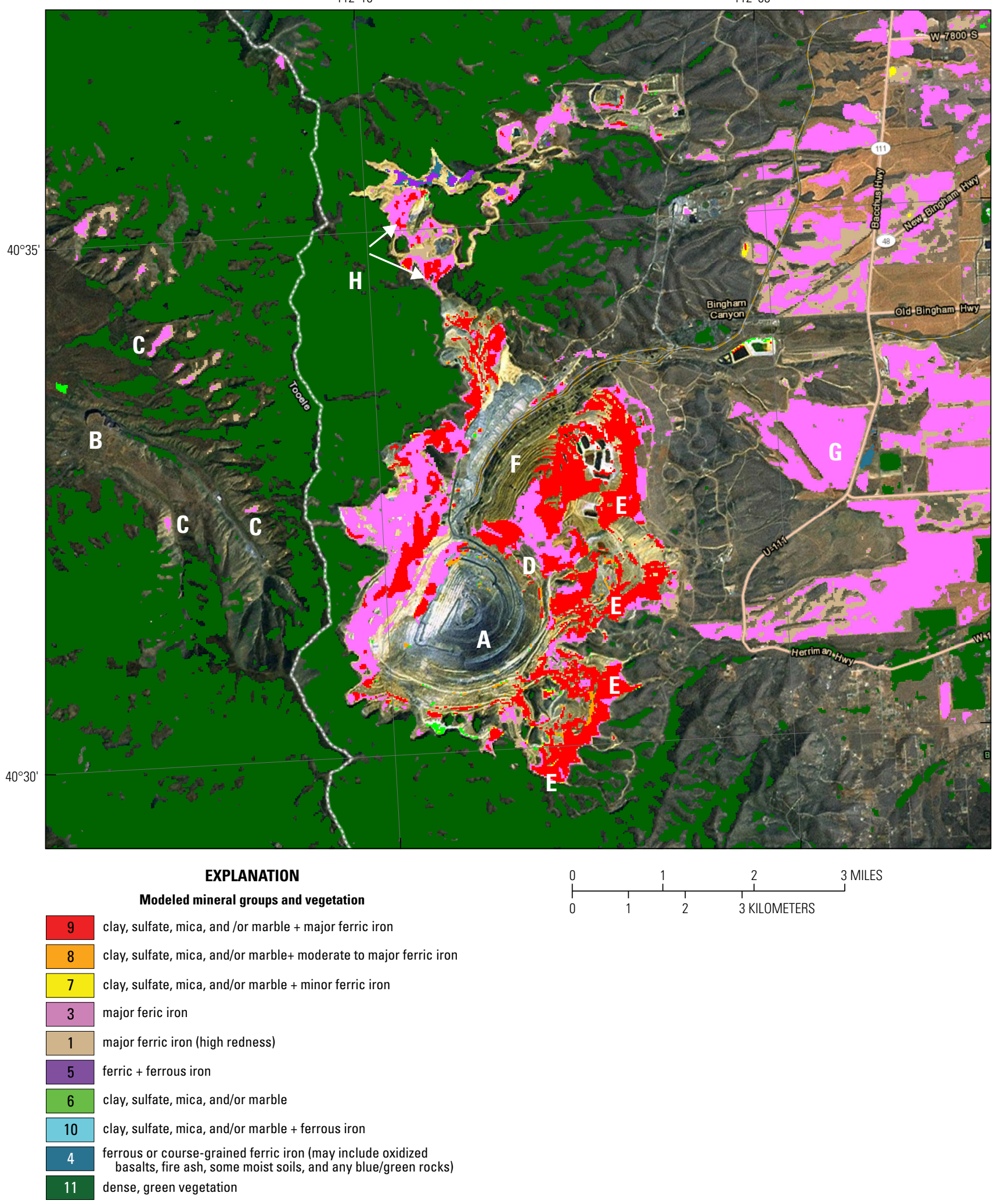


Figure 9 (following page). Mineral group map of the Bodie Hills and surrounding region, California/Nevada generated from Landsat 7 ETM+ data using the automated algorithm described herein. Embedded digital layers include statewide geologic maps (Ludington and others, 2005; Crafford, 2007), two ASTER-derived mineral maps (Rockwell, 2010), and various geographic basemaps (ESRI, 2012). The map also contains automated mapping results from two overlapping Landsat 7 ETM+ scenes that can be compared to each other. The northern scene was acquired on August 18, 2002, and the southern scene was acquired on July 25, 1999. A, quartz-alunite-bearing advanced argillic alteration mapped using ASTER data (Rockwell, 2010) and field work, including: A1, Red Wash; $A 2$, along fault zone on western flanks of Wassuk Range; $A 3$, rhyolite plug west of Aurora mining district; A4, advanced argillic alteration in which primarily ferric iron and a few pixels of the clay-sulfate-mica-marble mineral group were detected; B, site of Cinnabar Canyon sulfur deposit; $C$, intense, kaolinite-bearing argillic alteration, including: $\mathrm{C}$, kaolinized sinter with local ferric iron (mapped as classes 3, 8, and 9) east of East Brawley Peak and associated alunite; $\mathrm{C} 2$, Sweetwater Mountains; D, low-sulfidation deposits of the Bodie mining district and associated mill tailings; $\mathrm{E}$, argillized Cretaceous granite intrusion (mapped as ferric iron) surrounded by intense propylitic alteration (not mapped); $F$, hematite-bearing, oxidized basalts mapped as class $4 ; \mathrm{G}$, travertine hot springs with local nontronite (Rockwell, 2010 ) in which classes $1,3,6$, and 7 were identified; $H$, jarosite and smectite in pyritic rocks of the Borealis mine of Ramona mining district mapped as classes 3,8 , and 9 . Like the map sheet, the high-resolution version of this figure is a GeoPDF file containing multiple layers that can be visualized using the TerraGo® Toolbar plugin for Adobe Acrobat Reader. Click on figure for more detailed image. 


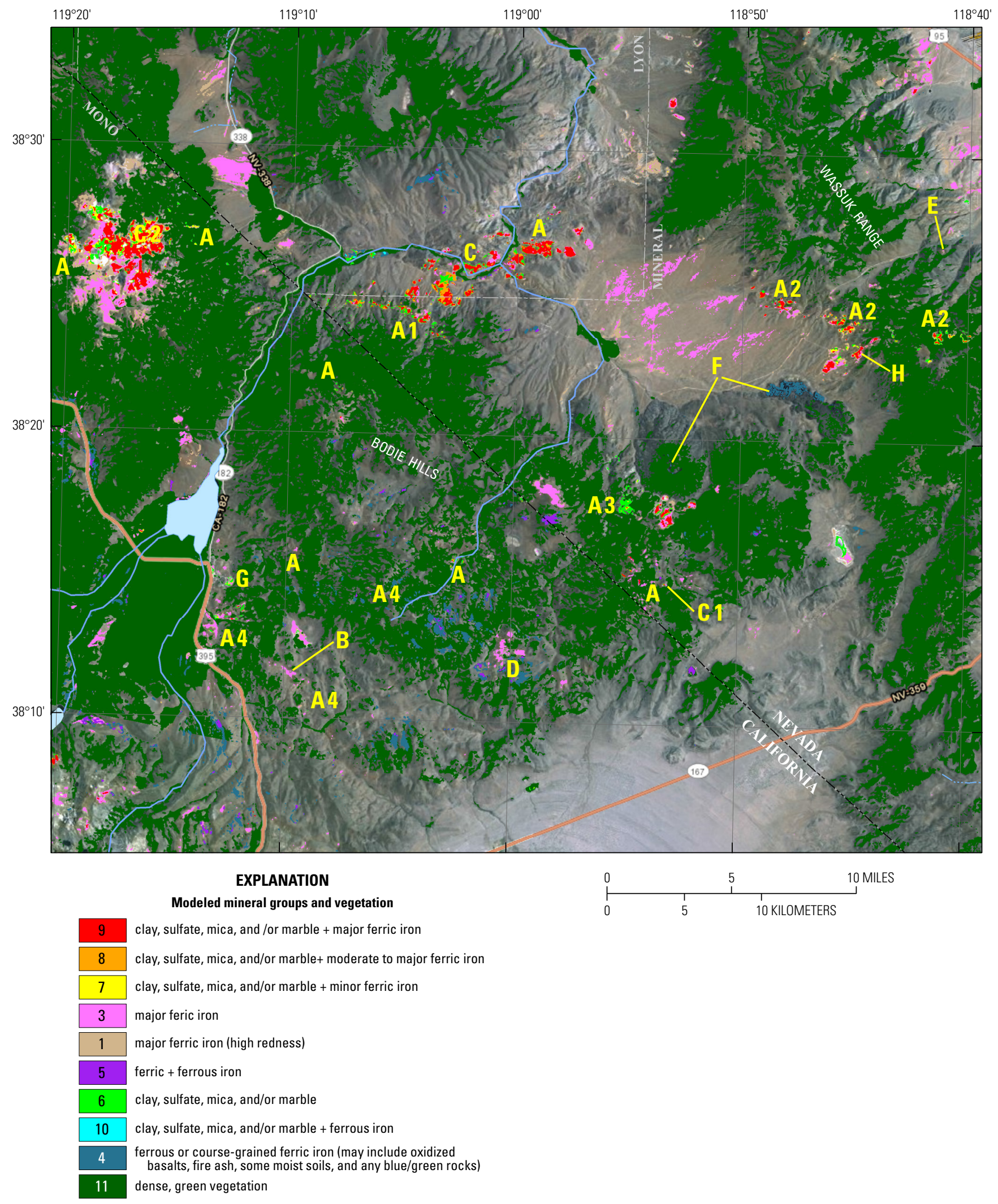


Figure 10 (following page). Mineral group map of the northern Marysvale volcanic field, Utah, generated from Landsat 7 ETM+ data using the automated algorithm described herein. Embedded digital layers include a geologic map (Rowley and others, 2002), mineral maps generated by spectroscopic analysis of ASTER data (Rockwell, 2009), a map of mineral groups and green vegetation generated by automated analysis of ASTER data (Rockwell, 2012), and various geographic basemaps (ESRI, 2012). A, advanced argillic (alunite, pyrophyllite), argillic (kaolinite, dickite), and phyllic alteration associated with Big Rock Candy Mountain replacement alunite deposit; B, Big Star natroalunite deposit; C, Yellow Jacket alunite deposit; D, Al Kee Mee alunite deposit; E, White Hills alunite deposit; F, White Horse alunite deposit; $G$, alunitic waste rock at loading site (approximately 80-100 m in diameter) on outskirts of town of Marysvale; $\mathrm{H}$, alluvium-bearing alunite, kaolinite, and ferric iron minerals derived from weathering of altered areas on Alunite Ridge and Deer Trail Mountain (Rockwell and others, 2005); I, Alunite Ridge magmatic steam alunite deposit; J, argillic alteration on summit of Deer Trail Mountain (mapped as ferric iron classes 1 and 3 only); $\mathrm{K}$, ferric iron identified in tailings from mill at Old Deer Trail mine; L, propylitically altered quartz-monzonite intrusion (Hoover Pluton) containing calcite, chlorite, and epidote that is unmapped by the Landsat data analysis except for two pixels of class 4 (ferrous iron) related to chlorite; M, alunite and kaolinite associated with Monroe hot springs and related alteration; $\mathrm{N}$, Red Narrows kaolinite mines with hematite (mined for fire brick) mapped as classes 1,3, and 9; 0, Marysvale Peak alunite deposit; $P$, Aluminum Queen alunite deposit; $\mathrm{Q}$, one pixel of class 1 (ferric iron) mapped in tailings from mill, Kimberly mining district; R, Box Creek kaolinite deposit; S, sericite, smectite, and minor kaolinite associated with weak argillic and regional propylitic alteration of Big John caldera fill; T, argillic alteration (kandite clay) associated with Saturday uranium prospect in northern Bullion Hills; $U$, altered rocks of the Winkleman replacement alunite deposit that were not identified; $V$, smectite in lacustrine deposits of the Sevier River Formation identified as classes 6 and 8 . Like the map sheet, the high-resolution version of this figure is a GeoPDF file containing multiple layers that can be visualized using the TerraGo® Toolbar plugin for Adobe Acrobat Reader. Click on figure for more detailed image. 


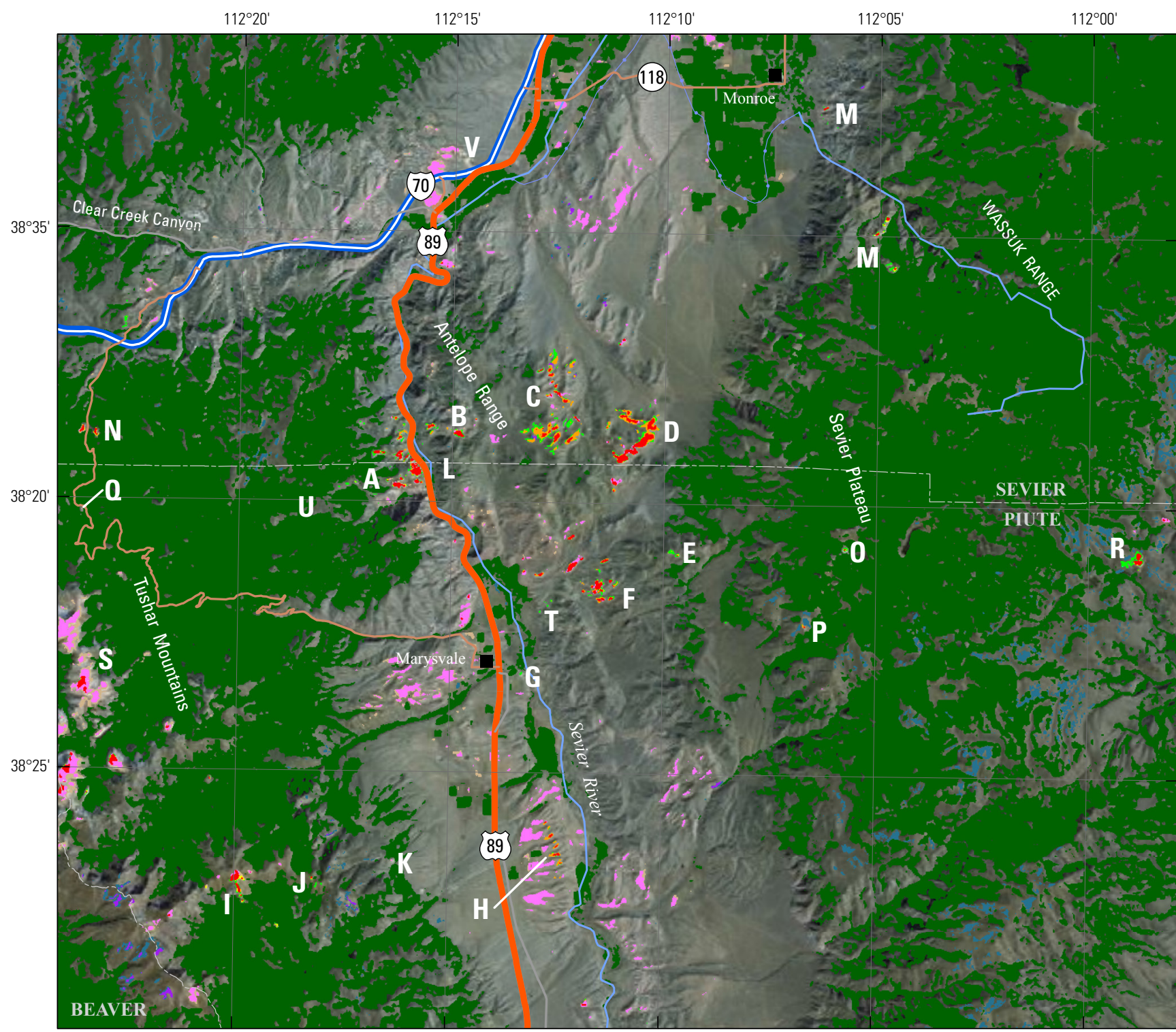

\section{EXPLANATION}

Modeled mineral groups and vegetation

\begin{tabular}{|c|}
\hline 9 \\
\hline 8 \\
\hline 7 \\
\hline 3 \\
\hline 1 \\
\hline 5 \\
\hline 6 \\
\hline 10 \\
\hline 4 \\
\hline 11 \\
\hline
\end{tabular}

clay, sulfate, mica, and /or marble + major ferric iron

clay, sulfate, mica, and/or marble+ moderate to major ferric iron

clay, sulfate, mica, and/or marble + minor ferric iron

major feric iron

major ferric iron (high redness)

ferric + ferrous iron

clay, sulfate, mica, and/or marble

clay, sulfate, mica, and/or marble + ferrous iron

ferrous or course-grained ferric iron (may include oxidized

basalts, fire ash, some moist soils, and any blue/green rocks)

dense, green vegetation

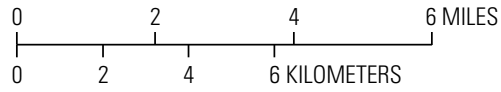




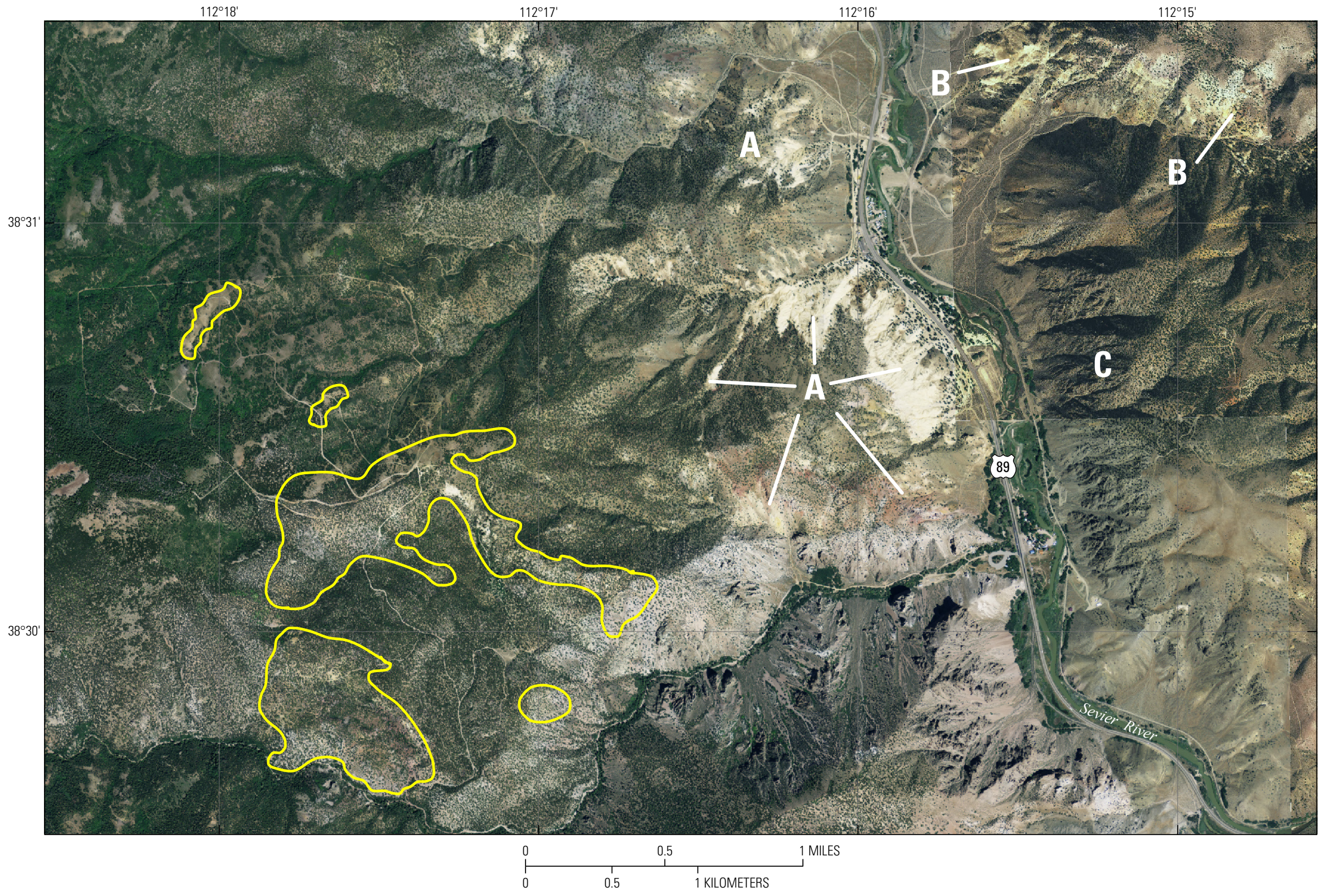

Figure 11. One-meter-resolution imagery from the USGS The National Map Viewer (http://raster.nationalmap.gov/ArcGIS/rest/services/TNM_Large_Scale_Imagery_Overlay/ MapServer) showing the Winkleman, Big Rock Candy Mountain, and Big Star replacement alunite deposits, Marysvale volcanic field, Utah. Altered rocks of the Winkleman deposit are outlined approximately in yellow. Note increased density of vegetation cover over Winkleman deposit related to increased elevation and precipitation. A, altered rocks of the Big Rock Candy Mountain deposit; B, Big Star deposit; C, note vegetation growing on upper parts of propylitically altered quartz-monzonite intrusion (Hoover Pluton) in which only two pixels of class 4 (ferrous iron absorptions in chlorite) were detected using the Landsat data. Click on figure for more detailed image. 


\section{Deficiencies of the Automated Analysis Methodology}

For the regional mapping effort, Landsat 7 scenes with minimal cloud cover and optimal solar illumination were selected for analysis. However, scenes with unclear atmospheres caused by dust, haze, clouds, fog, and smoke will show uncertain analysis results. Suitable Landsat data may not be available for all areas. False mineral group detections can occur in areas where seasonally dry, brown vegetation such as cheatgrass is present, especially in the northern Great Basin.

Because of the spectral coverage of Landsat TM band 7 with respect to the diagnostic absorptions of carbonate and $\mathrm{Mg}-\mathrm{OH}$ minerals, Landsat TM data analysis will not generally identify exposures of these minerals, except in cases of recrystallization where carbonate mineral abundance is increased (marbles), or when phyllosilicate minerals are also present. In addition, as vegetative cover is more common over carbonate-bearing rocks and soils than over argillically and pyritically altered rocks, the vegetation suppression logic will be more likely to remove pixels from the clay-sulfate-micamarble index in areas where carbonate and (or) $\mathrm{Mg}-\mathrm{OH}$ minerals are present. These features of Landsat data and the analysis technique will tend to skew results toward potentially acid-producing argillic and phyllic alteration.

In relatively rare cases, undisturbed, hydrolytically altered rocks containing clay, sulfate, and (or) mica minerals are partially covered by green vegetation. If the vegetative cover is sufficiently dense, the vegetation suppression logic may remove most or all pixels from the clay-sulfate-micamarble index. Therefore, if any pixels of this index are mapped in an area with vegetative cover, field checking and (or) additional data analysis should be performed to understand the true extent of altered rocks. Customized Landsat analysis without vegetation suppression, or ASTER data analysis, can be used as verification tools in such cases.

As described by Rockwell (2012) regarding the automated ASTER data analysis technique, any ratio-based spectral analysis algorithm will present "answers" for every material index. Even if no minerals of a type for which an index was designed to highlight are present in a scene, the high-end values of that index will be shown as a detection result. Therefore, the results of ratio-based analysis algorithms represent "high likelihood" maps where a particular material is most likely to occur. Substantial false mineral group detections related to the algorithm itself have not been observed in the testing performed for this study, as the mineral groups being identified are quite common on the Earth's surface.

As Landsat scenes are analyzed on a scene-by-scene basis, and as scene-wide statistics are used to calculate the values used for clipping off the low-end values of each index, material identifications across scene boundaries will not always be continuous. In addition, seasonal and annual variation between adjacent scenes may cause visible variation in mapped materials in scene overlap areas related to changes in vegetation abundance and dryness, soil moisture content, and atmospheric conditions.

\section{Conclusions}

Despite deficiencies in the quality and availability of Landsat TM data, the products generated by the automated process are ideal for efficient application to mineral resource and geoenvironmental assessments at regional and national scales. It is recommended that the Landsat TM-derived results be integrated with geologic maps and mineral maps generated from analysis of data from ASTER and (or) hyperspectral sensors to yield an optimal, hybrid map of hydrothermally altered areas. Such integration will improve accuracy and allow for characterization of alteration type.

\section{Acknowledgments}

The author would like to thank the USGS Earth Resources Observation and Science Center (EROS) for providing the Landsat 7 data, and Robert McDougal and Douglas Yager of the USGS for their helpful reviews of the manuscript, maps, and digital data.

\section{Disclaimer}

Any use of trade, firm, or product names is for descriptive purposes only and does not imply endorsement by the U.S. Government

\section{References}

Bove, D.J., Yager, D.B., Mast, M.A., and Dalton, J.B., 2007, Alteration map showing major faults and veins and associated water-quality signatures of the Animas River watershed headwaters near Silverton, southwest Colorado: U.S. Geological Survey Scientific Investigations Map 2976, 18-p. pamphlet, 1 pl., scale 1:24,000. Available at http://pubs. usgs.gov/sim/2976/.

Chander, Gyanesh, Markham, B.L., and Helder, D.L., 2009, Summary of current radiometric calibration coefficients for Landsat MSS, TM, ETM+, and EO-1 ALI sensors: Remote Sensing of Environment, v. 113, no. 5, p. 898-903.

Chavez, P.S., Jr., 1988, An improved dark-object subtraction technique for atmospheric scattering correction of multispectral data: Remote Sensing of Environment, v. 24, no. 3, p. 459-479.

Clark, R.N., 1999, Spectroscopy of rocks and minerals, and principles of spectroscopy, in Rencz, A.N., ed., Remote sensing for the earth sciences, in Ryerson, R.A., ed., Manual of remote sensing, v. 3: New York, John Wiley \& Sons, Inc., p. $3-58$. 
Clark, R.N., Swayze, G.A., Wise, R.A., Livo, E.K., Hoefen, T.M., Kokaly, R.F., and Sutley, S.J., 2007, USGS digital spectral library splib06a: U.S. Geological Survey Digital Data Series 231. Available at http://speclab.cr.usgs.gov/ spectral.lib06.

Crafford, A.E.J., 2007, Geologic map of Nevada: U.S. Geological Survey Data Series 249, 1 CD-ROM, 46 p., 1 pl. Available at http://pubs.usgs.gov/ds/2007/249/.

Crippen, R.E., 1989, Selection of Landsat TM band and bandratio combinations to maximize lithologic information in color composite displays, in Proceedings of the Seventh Thematic Conference on Remote Sensing Exploration Geology, Calgary, AB, Canada, Oct. 2-6, 1989, ERIM: Ann Arbor, Michigan, USA, p. 917-921.

Crowley, J.K., Brickey, D.W., and Rowan, L.C., 1989, Airborne imaging spectrometer data of the Ruby Mountains, Montana: Mineral discrimination using relative absorption band-depth images: Remote Sensing of Environment, v. 29, p. 121-134.

Cunningham, C.G., Rye, R.O., Rockwell, B.W., Kunk, M.J., and Councell, T.B., 2005, Supergene destruction of a hydrothermal replacement alunite deposit at Big Rock Candy Mountain, Utah - mineralogy, spectroscopic remote sensing, stable isotope and argon age evidences: Chemical Geology, v. 215, issues 1-4, p. 317-337. Available at http:// dx.doi.org/10.1016/j.chemgeo.2004.06.055.

Dalton, J.B., Bove, D.J., and Mladinich, C.S., 2004, Remote sensing characterization of the Animas River watershed, southwestern Colorado, by AVIRIS imaging spectroscopy: U.S. Geological Survey Scientific Investigations Report 2004-5203, 54 p. Available at http://pubs.usgs.gov/ sir/2004/5203/.

Dalton, J.B., Bove, D.J., Mladinich, C.S., and Rockwell, B.W., 2007, Imaging spectroscopy applied to the Animas River watershed and Silverton Caldera, in Church, S.E., von Guerard, Paul, and Finger, S.E., eds., Integrated investigations of environmental effects of historical mining in the Animas River watershed, San Juan County, Colorado: U.S. Geological Survey Professional Paper 1651, p. 143-159. Available at http://pubs.usgs.gov/ pp/1651/downloads/Vol1_combinedChapters/vol1_ chapE2.pdf.

Elvidge, C.D., and Lyon, R.J.P, 1985, Estimation of vegetation contribution to the $1.65 / 2.22$ micrometer ratio in the airborne TM imagery of the Virginia Range, Nevada: International Journal of Remote Sensing, v. 6, p. 137-155.

Environmental Systems Research Institute (ESRI), 2012, World imagery base layer: ESRI, i-cubed, USDA FSA, USGS, AEX, GeoEye, AeroGRID, Getmapping, IGP, accessed January 7, 2013, at http://goto.arcgisonline.com/ maps/World_Imagery.
Green, G.N., 1992, The digital geologic map of Colorado in ARC/INFO format: U.S. Geological Survey Open-File Report 92-0507, 9 p. Available at http://pubs.usgs.gov/ of/1992/ofr-92-0507/.

John, D.A., Rockwell, B.W., Henry, C.D., and Colgan, J.P., 2010, Hydrothermal alteration of the late Eocene Caetano ash-flow caldera, north-central Nevada-A field and ASTER remote sensing study, in Geological Society of Nevada Symposium, Great Basin evolution and metallogeny, Reno, Nev., May 14-22, 2010: Geological Society of Nevada 2010 Symposium Volume, p. 1055-1083.

Kaufman, Y.J., 1989, The atmospheric effect on remote sensing and its corrections, in Asrar, Ghassem, ed., Theory and application of optical remote sensing: New York, Wiley, p. $341 \mathrm{ff}$.

Knepper, D.H., Jr., 1989, Mapping hydrothermal alteration with Landsat Thematic Mapper data, in Lee, K., and others, eds., Remote sensing in exploration geology-Golden, Colorado to Washington D.C., June 30-July 8, 1989, Field Trip Guidebook, v. T182, p. 13-21: Washington, D.C., AGU, doi:10.1029/FT182p0013.

Knepper, D.H., Jr., 2010, Distribution of potential hydrothermally altered rocks in central Colorado derived from Landsat Thematic Mapper data: A geographic information system data set: U.S. Geological Survey Open-File Report 2010-1076, 14 p. Available at http://pubs.usgs.gov/ of/2010/1076/.

Kokaly, R.F., 2011, Detecting cheatgrass on the Colorado Plateau using Landsat data: A tutorial for the DESI software: U.S. Geological Survey Open-File Report 2010-1327, 88 p. Available at http://pubs.usgs.gov/ of $/ 2010 / 1327 /$.

Kokaly, R.F., Rockwell, B.W., Haire, S.L., and King, T.V.V., 2006, Characterization of post-fire surface cover, soils, and burn severity at the Cerro Grande Fire, New Mexico, using hyperspectral and multispectral remote sensing: Remote Sensing of Environment, v. 106, no. 3, p. 305-325. Available at http://dx.doi.org/10.1016/j.rse.2006.08.006.

Ludington, Steve, Moring, B.C., Miller, R.J., Stone, P.A., Bookstrom, A.A., Bedford, D.R., Evans, J.G., Haxel, G.A., Nutt, C.J., Flyn, K.S., and Hopkins, M.J., 2005, Preliminary integrated geologic map databases for the United States-Western States: California, Nevada, Arizona, Washington, Oregon, Idaho, and Utah, version 1.3, updated December 2007: U.S. Geological Survey Open-File Report 2005-1305, digital data. Available at http://pubs.usgs.gov/ of $/ 2005 / 1305 /$.

National Aeronautics and Space Administration (NASA), 2011, Chapter 1-Background to the Landsat Program: Landsat 7 Science Data Users Handbook. Available at http://landsathandbook.gsfc.nasa.gov/program/. 
Robinson, Douglas, Bevins, R.E., and Rowbotham, George, 1993, The characterization of mafic phyllosilicates in lowgrade metabasalts from eastern North Greenland: American Mineralogist, v. 78, p. 377-390.

Rockwell, B.W., 1989, Hydrothermal alteration mapping in spectral ratio feature space using TM reflectance data-Aurora mining district, Mineral County, Nevada, in Proceedings of the Seventh Thematic Conference on Remote Sensing Exploration Geology, Calgary, AB, Canada, Oct. 2-6, 1989, ERIM: Ann Arbor, Michigan, USA, p. 1189-1203.

Rockwell, B.W., 2004, Spectral variations in rocks and soils containing ferric iron hydroxide and (or) sulfate minerals as seen by AVIRIS and laboratory spectroscopy: U.S. Geological Survey Open-File Report 2004-1431, 24 p. Available at http://pubs.usgs.gov/of/2004/1431/.

Rockwell, B.W., 2009, Comparison of ASTER- and AVIRISderived mineral and vegetation maps of the White Horse replacement alunite deposit and surrounding area, Marysvale volcanic field, Utah: U.S. Geological Survey Scientific Investigations Report 2009-5117, 31 p. Available at http:// pubs.usgs.gov/sir/2009/5117/.

Rockwell, B.W., 2010, Mineral and vegetation maps of the Bodie Hills, Sweetwater Mountains, and Wassuk Range, California/Nevada, generated from ASTER satellite data: U.S. Geological Survey Scientific Investigations Map 3104, scale 1:62,000, 4 plates, pamphlet, 5 p. Available at http:// pubs.usgs.gov/sim/3104/.

Rockwell, B.W., 2012, Description and validation of an automated methodology for mapping mineralogy, vegetation, and hydrothermal alteration type from ASTER satellite imagery with examples from the San Juan Mountains, Colorado: U.S. Geological Survey Scientific Investigations Map 3190, 35 p. pamphlet, 5 map sheets, scale 1:100,000. Available at http://pubs.usgs.gov/sim/3190/.

Rockwell, B.W., Cunningham, C.G., Breit, G.N., and Rye, R.O., 2006, Spectroscopic mapping of the White Horse alunite deposit, Marysvale volcanic field, Utah-Evidence of a magmatic component: Economic Geology and the Bulletin of the Society of Economic Geologists, v. 101, no. 7, p. 1377-1395.

Rockwell, B.W., McDougal, R.R., and Gent, C.A., 2005, Remote sensing for environmental site screening and watershed evaluation in Utah mine lands-East Tintic Mountains, Oquirrh Mountains, and Tushar Mountains: U.S. Geological Survey Scientific Investigations Report 2004-5241, 84 p. Available at http://pubs.usgs.gov/ sir/2004/5241/. A full HTML-format version of the report is available at http://speclab.cr.usgs.gov/earth.studies/ Utah-1/sir5241txto_bredit.html.
Rowley, P.D., Cunningham, C.G., Steven, T.A., Workman, J.B., Anderson, J.J., and Theissen, K.M., 2002, Geologic map of the central Marysvale volcanic field, southwestern Utah: U.S. Geological Survey Geologic Investigations Series I-2645-A, scale 1:100,000. Available at http://pubs. usgs.gov/imap/i-2645-a/.

Song, Conghe, Woodcock, C.E., Seto, K.C., Lenney, M.P., and Macomber, S.A., 2001, Classification and change detection using Landsat TM data-When and how to correct atmospheric effects?: Remote Sensing of Environment, v. 75 , no. 2 , p. $230-244$.

Tweto, Ogden, 1979, Geologic map of Colorado: U.S. Geological Survey Special Geologic Map, scale 1:500,000.

Yager, D.B., Choate, LaDonna, and Stanton, M.R., 2008, Net acid production, acid neutralizing capacity, and associated mineralogical and geochemical characteristics of Animas River watershed igneous rocks near Silverton, Colorado: U.S. Geological Survey Scientific Investigations Report 2008-5063, 63 p. Available at http://pubs.usgs.gov/ sir/2008/5063/.

Yager, D.B., Johnson, R.H., Rockwell, B.W., Caine, J.S., and Smith, K.S., 2013, A GIS and statistical approach to identify variables that control water quality in hydrothermally altered and mineralized watersheds, Silverton, Colorado, USA: Environmental Earth Sciences, 26 p., doi: 10.1007/ s12665-013-2229-y. Available at http://link.springer.com/ article/10.1007\%2Fs12665-013-2229-y.

Publishing support provided by:

Denver Publishing Service Center

For more information concerning this publication, contact:

Center Director, USGS Central Mineral and Environmental Resources Science Center

Box 25046, Mail Stop 973

Denver, CO 80225

(303) 236-1562

Or visit the Central Mineral and Environmental Resources Science Center Web site at:

http://minerals.cr.usgs.gov/ 
